\title{
The anti-tumor efficacy of 3C23K, a glyco-engineered humanized anti-MISRII antibody, in an ovarian cancer model is mainly mediated by engagement of immune effector cells
}

Pauline Estupina ${ }^{1,2,3,4}$, Alexandre Fontayne ${ }^{5}$, Jean-Marc Barret $^{6}$, Nathalie Kersual ${ }^{1,2,3,4}$, Olivier Dubreuil 6 , Marion Le Blay ${ }^{1,2,3,4}$, Alexandre Pichard ${ }^{1,2,3,4}$, Marta Jarlier $^{4}$, Martine Pugnière ${ }^{1,2,3,4}$, Maëva Chauvin ${ }^{1,2,3,4}$, Thierry Chardès ${ }^{1,2,3,4}$, JeanPierre Pouget ${ }^{1,2,3,4}$, Emmanuel Deshayes ${ }^{4}$, Alexis Rossignol7, Toufik Abache ${ }^{5}$, Christophe de Romeuf ${ }^{5}$, Aurélie Terrier $^{5}$, Lucie Verhaeghe ${ }^{5}$, Christine Gaucher ${ }^{5}$, Jean-François Prost ${ }^{6}$, André Pèlegrin ${ }^{1,2,3,4, *}$, Isabelle Navarro-Teulon ${ }^{1,2,3,4, *}$

${ }^{1}$ IRCM, Institut de Recherche en Cancérologie de Montpellier, Montpellier, F-34298, France

${ }^{2}$ INSERM, U896, Montpellier, F-34298, France

${ }^{3}$ Université Montpellier, Montpellier, F-34298, France

${ }^{4}$ Institut Régional du Cancer de Montpellier, ICM, Montpellier, F-34298, France

${ }^{5}$ LFB Biotechnologies, Loos, F-59120, France

${ }^{6}$ GamaMabs Pharma, Toulouse cedex, F-31106, France

${ }^{7}$ Clean Cells, Boufféré, F-85600, France

*These authors are contributed equally to this work

Correspondence to: Isabelle Navarro-Teulon, email: isabelle.teulon@inserm.fr Keywords: immunotherapy, therapeutic antibody, ovarian cancer, GCT, MISRII

Received: November 15, $2016 \quad$ Accepted: February 11, $2017 \quad$ Published: February 24, 2017

Copyright: Estupina et al. This is an open-access article distributed under the terms of the Creative Commons Attribution License (CC-BY), which permits unrestricted use, distribution, and reproduction in any medium, provided the original author and source are credited.

\section{ABSTRACT}

Ovarian cancer is the leading cause of death in women with gynecological cancers and despite recent advances, new and more efficient therapies are crucially needed. Müllerian Inhibiting Substance type II Receptor (MISRII, also named AMHRII) is expressed in most ovarian cancer subtypes and is a novel potential target for ovarian cancer immunotherapy. We previously developed and tested 12G4, the first murine monoclonal antibody (MAb) against human MISRII. Here, we report the humanization, affinity maturation and glyco-engineering steps of $12 \mathrm{G} 4$ to generate the Fc-optimized 3C23K MAb, and the evaluation of its in vivo anti-tumor activity. The epitopes of 3C23K and 12G4 were strictly identical and 3C23K affinity for MISRII was enhanced by a factor of about $14\left(K_{D}=5.5 \times 10^{-11} \mathrm{M}\right.$ vs $\left.7.9 \times 10^{-10} \mathrm{M}\right)$, while the use of the EMABling ${ }^{\circledR}$ platform allowed the production of a low-fucosylated $3 \mathrm{C} 23 \mathrm{~K}$ antibody with a 30-fold $K_{D}$ improvement of its affinity to FcyRIIIa. In COV434-MISRII tumor-bearing mice, $3 \mathrm{C} 23 \mathrm{~K}$ reduced tumor growth more efficiently than $12 \mathrm{G} 4$ and its combination with carboplatin was more efficient than each monotherapy with a mean tumor size of 500,1100 and $100 \mathrm{~mm}^{3}$ at the end of treatment with $3 C 23 \mathrm{~K}(10 \mathrm{mg} / \mathrm{kg}$, Q3-4D12), carboplatin (60 $\mathrm{mg} / \mathrm{kg}, \mathrm{Q7D4})$ and $3 C 23 \mathrm{~K}+$ carboplatin, respectively. Conversely, 3C23K-FcKO, a 3C23K form without affinity for the FcyRIIIa receptor, did not display any anti-tumor effect in vivo. These results strongly suggested that 3C23K mechanisms of action are mainly Fc-related. In vitro, antibody-dependent cytotoxicity (ADCC) and antibody-dependent cell phagocytosis (ADCP) were induced by $3 C 23 \mathrm{~K}$, as demonstrated with human effector cells. Using human NK cells, $50 \%$ of the maximal lysis was obtained with a 46-fold lower concentration of low-fucosylated 3C23K (2.9 $\mathrm{ng} / \mathrm{ml}$ ) than of $3 \mathrm{C} 23 \mathrm{~K}$ expressed in CHO cells $(133.35 \mathrm{ng} / \mathrm{ml})$. As $3 \mathrm{C} 23 \mathrm{~K}$ induced strong ADCC with human PBMC but almost none with murine PBMC, antibody-dependent cell 


\begin{abstract}
phagocytosis (ADCP) was then investigated. 3C23K-dependent $(100 \mathrm{ng} / \mathrm{ml})$ ADCP was more active with murine than human macrophages (only $10 \%$ of living target cells vs. about $\mathbf{2 5} \%$ ). These in vitro results suggest that the reduced ADCC with murine effectors could be partially balanced by ADCP activity in in vivo experiments. Taken together, these preclinical data indicate that $3 \mathrm{C} 23 \mathrm{~K}$ is a new promising therapeutic candidate for ovarian cancer immunotherapy and justify its recent introduction in a phase I clinical trial.
\end{abstract}

\section{INTRODUCTION}

Ovarian cancer (OC) accounts for $3-5 \%$ of all cancers in women and is the leading cause of death in women with gynecological cancer $[1,2]$. The relative absence of specific signs and symptoms, coupled with the lack of reliable screening strategies, makes of OC a "silent killer". Indeed, it is often diagnosed at advanced stages when the disease has already spread to the abdominal cavity (over $70 \%$ at stage III or IV), thus resulting in low cure rates. The outcome for women with $\mathrm{OC}$ is generally poor, with an overall five year survival rate of $40 \%$ [3].

The current standard of care for OC involves a combination of debulking surgery and platinum-based chemotherapy (carboplatin combined with paclitaxel is the most effective chemotherapeutic regimen). Many women respond well initially to this therapeutic approach; however, 70 to $90 \%$ eventually will develop chemo-resistant recurrent OC [3].

Thus, to improve the clinical prognosis, new OC therapies are crucially needed. Various targeted strategies have been evaluated for OC management $[1,4,5]$ and many molecules are under investigation, among which agents to block growth factor receptors, such as monoclonal antibodies (MAbs), or tyrosine kinase inhibitors (TKIs), anti-angiogenetic molecules and DNA repair inhibitors, such as Poly(ADPribose) polymerase (PARP) inhibitors such olaparib (for review see [5]). However, these molecules only provide shortterm survival improvement [6] and more effective treatments to address chemo-resistant recurrent $\mathrm{OC}$ are not available yet. MAbs against surface antigens that are effective in different cancer types $[7,8]$ display no or extremely moderate activities when tested in OCs. Nevertheless, a few innovative targets, among which folate receptor [9] or angiopoietins [10], are currently evaluated. Finally, OC heterogeneity also complicates the targeted treatment strategies. The molecules evaluated in clinical trials do not seem to be clinically effective and with low toxicity in OCs [4]. Recently, in phase 2 trials, eight targeted drugs (gefitinib, imatinib, sorafenib, temsirolimus, mifepristone, enzastaurine, lapatinib and vorinostat) have produced objective response rates of less than $10 \%$ and stabilized the disease for six months in less than $25 \%$ of patients [11]. Moreover, besides olaparib and bevacizumab, no new therapy for OC has been approved in almost ten years [5]. New treatments are, therefore, required to improve OC outcome.

Müllerian Inhibiting Substance type II Receptor (MISRII, also named AMHRII) is a novel potential target for OC immunotherapy. The Müllerian Inhibiting Substance (MIS)/MISRII pathway plays a crucial role in Müllerian duct regression in males during fetal development. MISRII is a member of the TGF- $\beta$ family $(<30 \%$ homology with the other members) and has no homology with other human proteins [12]. MISRII expression profile in normal tissues is related to its involvement in gonad development and functions. Indeed, it is mainly expressed in granulosa cells of the ovary and in Sertoli and Leydig cells of the testis [13]. However, it is also detected in rodent uterus as well as in human endometrium, breast and prostate tissues and, surprisingly, in brain motor neurons [13-15]. MISRII is expressed in most human granulosa cell tumors (GCT), a rare OC form [16], and in the majority of human epithelial OCs (EOC) [17-20] as well as in the derived ascites, but only for a limited period of time [21]. Moreover, recombinant human MIS can inhibit the growth of mouse or human ovarian cancer cell lines in vitro and in vivo [22-24]. Therefore, MISRII represent a new candidate for targeted therapy in OC.

We developed and characterized $12 \mathrm{G} 4$, the first murine MAb against human MISRII [25]. This antibody showed good anti-tumor efficacy in vitro and in vivo using two OC xenograft models (NIH-OvCar3 and COV434-MISRII cells derived from human OCs) [20]. These findings confirm that anti-MISRII immunotherapy represents a new promising approach for treating MISRIIpositive OCs (especially GCT and EOC) and that the MAb 12G4 could be an attractive candidate to efficiently target this receptor. However, in the clinical practice, a mouse MAb could elicit human anti-murine antibody (HAMA) responses in patients [26]. Therefore, the aim of this study was to generate a humanized version of $12 \mathrm{G} 4$ and to demonstrate its activity against ovarian cancer cells in vitro and in vivo. Chimerization, complementarity determining region (CDR) grafting and molecular evolution were used to generate the humanized $3 \mathrm{C} 23 \mathrm{~K}$ MAb starting from $12 \mathrm{G} 4$. Moreover, to restore the binding affinity that was partially lost during the initial CDR grafting step, the framework (FR) sequences of the variable region were fine-tuned by using phage-displayed combinatorial libraries [27]. The EMABling ${ }^{\circledR}$ technology was also used to produce a low-fucosylated $3 \mathrm{C} 23 \mathrm{~K}$ with the aim of increasing its antibody-dependent cell-mediated cytotoxicity (ADCC) and consequently its anti-tumor activity [28-30].

\section{RESULTS}

\section{Humanization: from the murine MAb 12G4 to the humanized MAb 3C23K}

\section{Chimerization, humanization and affinity maturation}

The $3 \mathrm{C} 23 \mathrm{~K}$ humanized antibody was initially derived from the variable regions of the murine $12 \mathrm{G} 4$ 
MAb [25]. The humanization procedure included CDR grafting (MAb h12G4) and affinity maturation by random mutagenesis and phage display, leading to the final molecule $3 \mathrm{C} 23 \mathrm{~K}$.

In the first step, candidate human templates for CDR grafting were identified by separately entering the sequences of the VL and VH domains in the IMGT/ DomainGapAlign search program [31] and by restricting the search to human sequences in IMGT/GENE-DB [32]. The closest human VH gene, IGHV1-3*01, showed $67.34 \%$ of identity with the murine counterpart. This identity rose up to $92.85 \%$ after grafting the murine $12 \mathrm{G} 4$ CDR-IMGT into the human FR-IMGT. The closest human VL gene, IGK $1-9 * 01$, showed $62.76 \%$ of identity with the murine counterpart. However, IGKV1-5*01 was preferred because the IMGT/GeneFrequency tool [31] indicated that IGK $1-9 * 01$ is not very frequently expressed. IGKV1-5*01 has an identity of $58.51 \%$ with the VL of $12 \mathrm{G} 4$ that was increased to $88.29 \%$ after grafting.

After production in YB2/0 cells and purification, the binding capacity of humanized $12 \mathrm{G} 4$ (h12G4) to the MISRII-Fc fusion protein was tested and compared with that of mouse 12G4 by ELISA (Figure 1A). The choice of a recombinant MISRII protein was based on the observation that MISRII expression in cell lines derived from OC and $\mathrm{OC}$ ascites rapidly and progressively decreases after longterm culture [21], thus limiting the result reproducibility. Compared with chimeric (ch12G4), the binding capacity of h12G4 was about 20 -fold reduced. Therefore, to restore h12G4 binding affinity, both variable domains of the humanized antibody were modified using the MutaGen $^{\text {TM }}$ technology [27, 33], a random mutagenesis method. Based on the scFv format of h12G4, libraries were created and mixed before variant selection through six rounds of phagedisplay panning on immobilized recombinant MISRII-Fc fusion protein. Among the 113 clones selected by biopanning, 43 exhibited higher binding affinity than $\mathrm{h} 12 \mathrm{G} 4$ by phageELISA assay (data not shown). These clones carried and/or shared mutations at positions known to affect the structural conformation of the CDR loops (I54T in the VL of clone $3 \mathrm{C} 23$ ), or the orientation of the $\mathrm{V}$ domains (L50P shared by the $\mathrm{VH}$ of clones $4 \mathrm{C} 35$ and $5 \mathrm{~B} 81$ ). Other mutations were located inside the CDR-L2 loop (E68K shared by the VL of clones $4 \mathrm{C} 35$ and $6 \mathrm{~B} 78$ ), or were modified by the humanization process (E68K in the VL of clones $4 \mathrm{C} 35$ and 6B78). To examine the real effect of these mutations independently of the $\mathrm{scFv}$ format, the corresponding $\mathrm{VH}$ and $\mathrm{VL}$ were subcloned in a bicistronic vector that allows the expression of $\mathrm{Fab}$ fragments in the periplasmic space of E.coli HB2151 cells. The Fab variants 6B78, 5B42, 4C35 and $3 \mathrm{C} 23$ showed a significant increase in binding affinity, compared with h12G4, in an ELISA assay with immobilized recombinant MISRII-Fc (Figure 1B and Supplementary Figure 1A and 1B). The clones $6 \mathrm{~B} 78$ and $4 \mathrm{C} 35$ harbored the same mutation $(\mathrm{E} 68 \mathrm{~K})$ in the $\mathrm{VL}$, whereas clone $5 \mathrm{~B} 42$ had a mutation in the VL (S56P). The mutation L50P (clone
5B81) had no effect on binding to recombinant MISRII-Fc (Supplementary Figure 1C). Despite the binding affinity improvement, none of the selected variants reached the binding capacity of the parental mouse antibody. Therefore, to further increase affinity, the mutation E68K (clones 6B78 and $4 \mathrm{C} 35$ ) was introduced in clone $3 \mathrm{C} 23$ to generate clone $3 \mathrm{C} 23 \mathrm{~K}$ that showed a binding affinity close to that of the parental 12G4 mouse antibody (Figure 1B). To better define the binding characteristics, clone $3 \mathrm{C} 23 \mathrm{~K}$ was reformatted as an IgG1 antibody, produced in YB2/0 cells and analyzed by surface plasmon resonance (SPR). The $3 \mathrm{C} 23 \mathrm{~K}$ antibody exhibited a higher binding affinity $\left(\mathrm{K}_{\mathrm{D}}=5.5 \times 10^{-11} \mathrm{M}\right)$ than mouse $12 \mathrm{G} 4\left(\mathrm{~K}_{\mathrm{D}}=7.9 \times 10^{-10} \mathrm{M}\right)$. This latter value was very close to the value published in the initial description of the MAb 12G4 $\left(\mathrm{K}_{\mathrm{D}}=8.6 \times 10^{-10} \mathrm{M}\right)[25]$. The gain of binding affinity was also confirmed by flow cytometry using COV434-MISRII cells (Figure 1C).

\section{Epitope mapping of $3 \mathrm{C} 23 \mathrm{~K}$}

To analyze the epitopes recognized by $3 \mathrm{C} 23 \mathrm{~K}$, 13 overlapping peptides of 20 amino acids each were produced. These peptides covered the first 132 amino acids of MISRII extracellular domain (Table 1). As positive control, a peptide centered on the epitope $\mathrm{D}^{53} \mathrm{RAQVEM}$ of the murine 12G4 MAb was used [25]. Peptides were immobilized on glass slides and incubated with $12 \mathrm{G} 4$ or $3 \mathrm{C} 23 \mathrm{~K}$, followed by an appropriate fluorescently labeled polyclonal anti-IgG secondary antibody. The obtained fluorescence signal patterns revealed that, albeit with some differences in the fluorescence AU values, both $12 \mathrm{G} 4$ and $3 \mathrm{C} 23 \mathrm{~K}$ recognized only the two peptides (P5 and $\mathrm{P} 6$ ) that contain the DRAQVEM sequence (Table 1). This demonstrates that the humanization and affinity maturation processes did not modify the epitope recognized by $3 \mathrm{C} 23 \mathrm{~K}$ compared with the parental mouse antibody $12 \mathrm{G} 4$.

Then, the potential cross-reactivity of $3 \mathrm{C} 23 \mathrm{~K}$ with other human proteins that display homology with the DRAQVEM sequence was evaluated. BLAST analysis identified 13 human proteins harboring homologous sequences (Table 2). Peptides of 20 amino acids containing these sequences were synthetized and immobilized on glass slides, as before. $3 \mathrm{C} 23 \mathrm{~K}$ bound weakly to only three of them (Table 2). Indeed, the fluorescence AU values obtained for IEEAFARAQVEMKAVHENLA from the kinesinlike protein KIFC3, for ARLELERAQLEMQSQQLRES from the brain leucine zipper (BRLZ) protein and for QLDFFDRAQIEQVIANCEHK from the Nup205 nucleoporin were $6 \%, 22 \%$ and $10 \%$, respectively, of the value obtained with the MISRII DRAQVEM peptide. Moreover, these three proteins are localized in the cytoplasm or in the nucleus and therefore, should not be accessible to the $\mathrm{MAb} 3 \mathrm{C} 23 \mathrm{~K}$ in vivo.

\section{Structural comparison of the CDRs of ch12G4, h12G4 and $3 \mathrm{C} 23 \mathrm{~K}$}

The humanization and maturation processes resulted in several variants with modifications in the light 
and heavy chain sequences and with different affinities for MISRII. The same homology building approach was used to generate 3D models of the antibody before and after humanization and before and after affinity maturation (Figure 1D). Superimposition of the ch12G4 and h12G4 models showed that, despite differences in the primary sequence, the spatial conformation of the main chain atoms was very similar in both antibodies, as indicated by the low rmsd value of $1.179 \AA$ (Figure 1D). Superimposition of h12G4 and $3 \mathrm{C} 23 \mathrm{~K}$ also showed that the four mutations generated during the affinity maturation process (I54T, S56P, E68K and Q3R) had a very small effect on the antibody topology, as indicated by the very low rmsd value $(0.126 \AA)$ (Figure $1 D)$. Taken together, these results suggest that the binding affinity variations observed during 12G4 humanization were not related to major changes in CDR spatial conformation. Nevertheless, it is worth to note that the three VL mutations are located inside (S56P) or surrounding (E68K, I54T) the CDR-L2 hypervariable loop. Although our molecular model did not reveal any major conformational change, it is not possible to exclude that these mutations, particularly S56P and I54T in the Vernier zone, affected CDR-L2 conformation or flexibility upon interaction with MISIIR. Moreover, CDR-L2 is close to CDR-H3 that contains two arginine residues (R106 and R114) critical for the binding to MISRII. Indeed, their substitution by alanine induced a drastic loss of binding affinity (as determined by alanine scanning experiments, data not shown). Therefore, the mutations in the CDR-L2 region could indirectly affect the antibody affinity by positioning the side-chain of the CDR-H3 arginine residues for optimal interaction (Supplementary Figure 1D).

Then, the effect of these mutations on the antibody electrostatic surface potential was calculated with the Delphi program. The humanization of 12G4 introduced a highly negative patch (red) in a highly positive region (blue), as a consequence of the A68E mutation (Figure 1E). During the affinity maturation, the glutamic acid residue was then replaced by a lysine residue (K68), restoring the initial charge in this region and contributing to the increase in binding affinity.

3C23K production in YB2/0, CHO or HEK293 cells, glycosylation analysis and effect on binding to $\mathrm{Fc} \gamma$ receptors

Oligosaccharide analysis of $3 \mathrm{C} 23 \mathrm{~K}$ expressed in YB2/0 (EMABling ${ }^{\circledR}$ version; 3C23K) [30], CHO-S (3C23K-CHO) or HEK293 (3C23K-HEK293) cells (used as comparators for functional assays) revealed two clearly different glycosylation patterns (Supplementary Figure 1E). The percentages of fucosylated, galactosylated and bisecting GlcNAc isoforms were 33.0\%, 57.2\% and $1.8 \%$ for $3 \mathrm{C} 23 \mathrm{~K}$ and $94.6 \%, 54.4 \%$ and $2.0 \%$, for $3 \mathrm{C} 23 \mathrm{~K}-$ $\mathrm{CHO}$, respectively. The effect of these glycosylation differences on the binding to FcyRs was analyzed by SPR. Binding affinity for hFc $\gamma$ RIIIa and hF c $\gamma$ RIIIb was clearly increased following fucose reduction (1-12 nM and $86.0 \mathrm{nM}$ for $3 \mathrm{C} 23 \mathrm{~K}$ compared with $31-164 \mathrm{nM}$ and $378 \mathrm{nM}$ for 3C23K-HEK293, respectively), but not for the other Fc $\gamma$ Rs (hFc $\gamma$ RI, hFc $\gamma$ RIIa, hFc $\gamma$ RIIb) (Table 3).

\section{In vivo, ${ }^{177} \mathrm{Lu}-3 \mathrm{C} 23 \mathrm{~K}$ preferentially accumulates in ovarian tumor cell xenografts that express MISRII}

A SPECT/CT-based study was designed to evaluate the in vivo biodistribution of the $3 \mathrm{C} 23 \mathrm{~K}$ MAb in nude mice xenografted with COV434-MISRII or COV434-WT (very low MISRII expression) cells. For this purpose, 3C23K was radiolabeled with Lutetium 177, a radionuclide that could be used for diagnostic purposes. Representative SPECT/CT images at 72 hours post-injection (Figure 2A) clearly showed that ${ }^{177} \mathrm{Lu}-3 \mathrm{C} 23 \mathrm{~K}$ specifically localized in COV434-MISRII, but not in COV434-WT cell-derived tumor xenografts. To confirm the specificity of $3 \mathrm{C} 23 \mathrm{~K}$ binding in vivo, an isotope dilution experiment was carried out in which a large molar excess of non-radiolabeled $3 \mathrm{C} 23 \mathrm{~K}(20 \mathrm{mg} / \mathrm{kg}$; therapeutic dose) was injected 10 minutes before injection of ${ }^{177} \mathrm{Lu}-3 \mathrm{C} 23 \mathrm{~K}$. Pre-injection of unlabeled MAb $3 \mathrm{C} 23 \mathrm{~K}$ decreased ${ }^{177} \mathrm{Lu}-3 \mathrm{C} 23 \mathrm{~K}$ uptake in COV434-MISRII tumors to a level similar to that observed in COV434-WT xenografts (Figure 2B).

\section{C23K anti-tumor efficacy in vivo}

We previously verified in mice xenografted with COV34-MISRII cells (OC model) that: (i) 3C23K antitumor efficacy was not significantly different when using different treatment schedules ( 2 or 3 injections of $10 \mathrm{mg} / \mathrm{kg}$ $3 \mathrm{C} 23 \mathrm{~K} /$ week for 4 or 6 weeks) (Supplementary Figure 2A) and (ii) the anti-tumor activity of $3 \mathrm{C} 23 \mathrm{~K}$ administered intraperitoneally (i.p.) or intravenously $(10 \mathrm{mg} / \mathrm{kg}$, Q34D12) was almost similar (Supplementary Figure 2B). Based on these data, the following three experiments were designed with the simplest protocol (i.e., 2 i.p. injections per week for 4 or 6 weeks).

\section{C23K reduces COV434-MISRII tumor growth more efficiently than 12G4}

To compare $3 \mathrm{C} 23 \mathrm{~K}$ and $12 \mathrm{G} 4$ efficacy, $12 \mathrm{G} 4$, $3 \mathrm{C} 23 \mathrm{~K}$ or vehicle $(\mathrm{NaCl})$ were administered i.p. in mice with established COV434-MISRII cell-derived tumors (7-8 mice/group) twice a week for 6 weeks (18 injections in total) at about $10 \mathrm{mg} / \mathrm{kg} /$ injection, Q2-3D18. Both $12 \mathrm{G} 4$ and $3 \mathrm{C} 23 \mathrm{~K}$ significantly inhibited tumor growth compared with vehicle ( $p=0.0012$ and $p=0.0001$, respectively) (Figure 3A1). However, 3C23K displayed a stronger anti-tumor activity than $12 \mathrm{G} 4$, as the tumor volumes in this group were significantly smaller than in the $12 \mathrm{G} 4$ group at all times points $(p<0.001)$. In this model and at this dose, 12G4 displayed only a partial anti-tumor activity, compared with vehicle. Indeed, the KaplanMeier survival curves highlighted a significant difference 

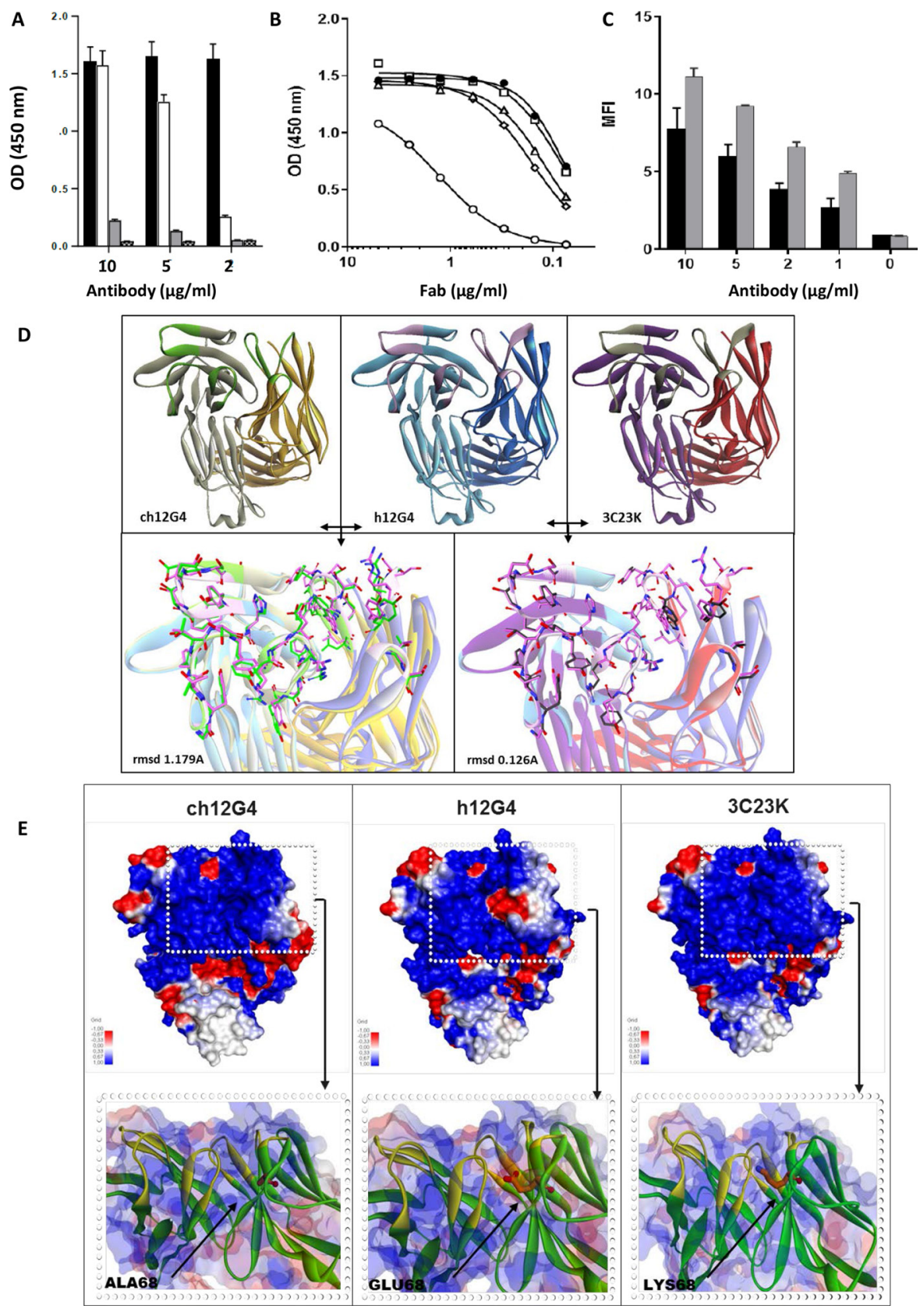

Figure 1: Humanization of the murine MAb 12G4. Panel (A) Comparison of the binding capacity of murine and humanized 12G4. In ELISA, MISRII-Fc was coated on titration plates and then antibodies were added at different concentrations before detection with the appropriate HRP-labeled secondary antibody. Black bars: murine 12G4; white bars: humanized 12G4 (h12G4), gray bars: uncoated control with murine 12G4; dashed bars uncoated control with h12G4. Panels B-C: Comparison of the binding capacity of humanized 12G4 (h12G4) and of the different affinity matured variants with that of murine 12G4. (B) In ELISA assays, microtiter plates were coated with MISRII-Fc and the tested Fabs were added at different concentrations before detection with an HRP-labeled secondary antibody. Black circles $(\bullet)$, murine $12 \mathrm{G} 4$; open circles $(\mathrm{O})$, h12G4; open diamonds $(\diamond), 6 \mathrm{~B} 78$; open triangles $(\Delta)$, 3C23; open squares $(\square)$, 3C23K; (C) By cytometry analysis of COV434-MISRII cells using the antibodies $12 \mathrm{G} 4$ and $3 \mathrm{C} 23 \mathrm{~K}$ at $0,1,2,5 \mathrm{or} 10 \mu \mathrm{g} / \mathrm{ml}$. Black bars: murine 12G4; Grey bars: 3C23K. Panels (D, E) Modeled structure of chimeric 12G4 (ch12G4), humanized 12G4 (h12G4) and affinity matured $3 \mathrm{C} 23 \mathrm{~K}$ using a sequence homology approach. Templates selected to build the initial model were the PDB structures 2OSL (for the light and heavy chains of ch12G4) and 3EO9 and 2EH7 (for the light and heavy chain of h12G4, respectively). (D) CDR loops, shown as sticks and with a different color than the light and heavy chains, were specifically rebuilt and refined using the Discovery Studio software (Modeler and Looper algorithms). The $3 \mathrm{C} 23 \mathrm{~K}$ model was built from the $\mathrm{h} 12 \mathrm{G} 4$ model by replacing the four residues mutated during the maturation affinity process (I47T, S49P, E54K, Q216R showed as sticks and balls). The conformation of the mutated residues and of the surrounding residues that lie within a $5 \AA$ cutoff radius was optimized using the MODELER algorithm. (E) The electrostatic potentials of the three MAbs, calculated with the Delphi program included in the Discovery studio software, are visualized using a surface graphic view. Highly negative and highly positive regions are indicated in red and blue, respectively. 
Table 1: Epitope mapping: mouse 12G4 vs human 3C23K

\begin{tabular}{|c|c|c|c|c|}
\hline \multicolumn{3}{|c|}{ Position AA } & \multirow{2}{*}{$\begin{array}{c}\text { 12G4 binding (AU fluorescence) } \\
<1000\end{array}$} & \multirow{2}{*}{$\frac{\text { 3C23K binding (AU fluorescence) }}{<1000}$} \\
\hline Peptide 1 & $1-20$ & PPNRRTCVFFEAPGVRGSTK & & \\
\hline Peptide 2 & $11-30$ & EAPGVRGSTKTLGELLDTGT & $<1000$ & $<1000$ \\
\hline Peptide 3 & $21-40$ & TLGELLDTGTELPRAIRCLY & $<1000$ & $<1000$ \\
\hline Peptide 4 & $31-50$ & ELPRAIRCLYSRCCFGIWNL & $<1000$ & $<1000$ \\
\hline Peptide 5 & $41-60$ & SRCCFGIWNLTQDRAOVEMQ & $37300 \pm 5000$ & $28400 \pm 5000$ \\
\hline Peptide 6 & $51-70$ & TQDRAQVEMQGCRDSDEPGC & $24500 \pm 4300$ & $26000 \pm 5100$ \\
\hline Peptide 7 & $61-80$ & GCRDSDEPGCESLHCDPSPR & $<1000$ & $<1000$ \\
\hline Peptide 8 & $71-90$ & ESLHCDPSPRAHPSPGSTLF & $<1000$ & $<1000$ \\
\hline Peptide 9 & $81-100$ & AHPSPGSTLFTCSCGTDFCN & $<1000$ & $<1000$ \\
\hline Peptide 10 & $91-110$ & TCSCGTDFCNANYSHLPPPG & $<1000$ & $<1000$ \\
\hline Peptide 11 & $101-120$ & ANYSHLPPPGSPGTPGSQGP & $<1000$ & $<1000$ \\
\hline Peptide 12 & $111-130$ & SPGTPGSQGPQAAPGESIWM & $<1000$ & $<1000$ \\
\hline Peptide 13 & $113-132$ & GTPGSQGPQAAPGESIWMAL & $<1000$ & $<1000$ \\
\hline Control & 47 & WNLTQDRAOVEMQGCRDSDE & $11200 \pm 2000$ & $16600 \pm 2300$ \\
\hline
\end{tabular}

in survival between the $12 \mathrm{G} 4$ - and $3 \mathrm{C} 23 \mathrm{~K}$-treated groups $(p=0.0024)$ (Figure 3A2). This could be attributed to a better efficiency of human IgG1 than murine IgG1 in our mouse model (human cell-derived tumors in nude mice) due to the lower affinity of Fc $\gamma$ RIIIa for mouse IgG1, as already reported by Bruhns et al. [34]. Moreover, Overdijk et al [35] demonstrated that human IgG1 and IgG2 activate murine polymorphonuclear leukocytes (PMNs) more potently than mouse IgG1.

\section{Mutated 3C23K that cannot bind to Fc receptors has no effect on COV434-MISRII tumor growth}

A second study was designed to evaluate and compare in mice bearing COV434-MISRII tumors the efficacy of $3 \mathrm{C} 23 \mathrm{~K}$ (low fucose on the $\mathrm{Fc}$ fragment), $3 \mathrm{C} 23 \mathrm{~K}-\mathrm{CHO}$ (high-fucose form) and of $3 \mathrm{C} 23 \mathrm{~K}$ with a mutation in the $\mathrm{Fc}$ domain $(3 \mathrm{C} 23 \mathrm{~K}-\mathrm{FcKO}$; no binding to $\mathrm{Fc}$ receptors) (9 animals/group; $10 \mathrm{mg} / \mathrm{kg}$, one i.p. injection/week for 4 weeks, Q7D4). 3C23K and 3C23K$\mathrm{CHO}$ significantly reduced tumor growth compared with $3 \mathrm{C} 23 \mathrm{~K}-\mathrm{FcKO}$ (respectively, $p=0.023$ and $p<0.0001$ ) or vehicle $(\mathrm{NaCl})$ (respectively, $p=0.012$ and $p<0.0001$ ) (Figure 3B1). Similarly, survival was significantly higher in mice treated with $3 \mathrm{C} 23 \mathrm{~K}$ and $3 \mathrm{C} 23 \mathrm{~K}-\mathrm{CHO}$ than with $3 \mathrm{C} 23 \mathrm{~K}-\mathrm{FcKO}$ or vehicle $(p<0.0001)$ (Figure 3B2). As already described by different authors for other MAbs, nude mice are not a good model to highlight differences in anti-tumor efficacy between antibodies with different levels of fucosylation [36]. Such difference might only be observed using human FcyRIII transgenic mice, as demonstrated by Junttilia et al. for the anti-HER 2 antibody trastuzumab [36].

\section{$3 \mathrm{C} 23 \mathrm{~K}$ anti-tumor effect is enhanced when combined with carboplatin}

A third in vivo study was performed to evaluate the anti-tumor activity of 3C23K (10 mg/kg, Q3-4D12) and carboplatin $(60 \mathrm{mg} / \mathrm{kg}$ Q7D4; a suboptimal and non-toxic dose) as monotherapies or in association in female nude mice xenografted with COV434-MISRII cells. Vehicle $(\mathrm{NaCl})$ and the irrelevant antibody R565 $(10 \mathrm{mg} / \mathrm{kg}, \mathrm{Q} 3-$ 4D12), alone or in association with carboplatin, were used as controls (9 animals/group). $3 \mathrm{C} 23 \mathrm{~K}$ alone and the $3 \mathrm{C} 23 \mathrm{~K}+$ carboplatin combination had the highest inhibitory effect on tumor growth over time, compared with $\mathrm{NaCl}(p<0.001)$ (Figure 3C1). At the end of the experiment, only 23 of the 54 analyzed mice had a tumor volume greater than $2000 \mathrm{~mm}^{3}$. Survival was significant longer in the $3 \mathrm{C} 23 \mathrm{~K}$ group than in the vehicle and $\mathrm{R} 565$ groups $(p<0.001)$. No difference was observed between treatment with vehicle and R565 ( $p=0.796)$ (Figure 3C2). In these conditions, $3 \mathrm{C} 23 \mathrm{~K}$ alone displayed a significantly greater anti-tumor activity than carboplatin alone $(p<0.001)$, and the carboplatin $+3 \mathrm{C} 23 \mathrm{~K}$ combination displayed a stronger anti-tumor activity $(p<0.001)$ than each compound alone compared with vehicle (Figure 3C2). The association carboplatin $+3 \mathrm{C} 23 \mathrm{~K}$ showed an additive effect in this in vivo experiment. Treatments did not significantly affect body weight and could not been considered as toxic. 
Table 2: Binding of $3 \mathrm{C} 23 \mathrm{~K}$ to 13 human sequences homologous to the 7AA epitope sequence DRAQVEM identified by BLAST

\begin{tabular}{|c|c|c|}
\hline Protein* & Peptide sequence** & 3C23K binding (AU fluorescence) \\
\hline MISRII (Q16671) & WNLTQDRAOVEMQGCRDSDE & $5200 \pm 600$ \\
\hline kinesin-like protein KIFC3 (AAH47051/Q9BVG8) & IEEAFA $\underline{\text { RAOVEMKAVHENLA }}$ & $310 \pm 80$ \\
\hline BRLZ, brain leucine zipper protein (AAR83719/A6NC98) & ARLELERAQLEMQSQQLRES & $1100 \pm 100$ \\
\hline unnamed protein product (BAG62992/B4DWD0) & NQLKDAIAQVEMDLKRLRDP & $<200$ \\
\hline integrin alpha D, CD11d (AAB60630/Q13349) & GQEAFMRAQMEMVLEEDEVY & $<200$ \\
\hline tektin 2 (EAX07391/Q9UIF3) & SRFNKDRAEAEMKAATELRE & $<200$ \\
\hline DNA polymerase iota chain A (3H40_A/Q9UNA4) & VDLDCFY $\underline{\text { AOVEMISNPELKD }}$ & $<200$ \\
\hline Nup205 (nucleoporin) (AAH44255/Q92621) & QLDFFDRAQIEQVIANCEHK & $520 \pm 20$ \\
\hline integrin alpha D precursor (NP_005344/Q59H14) & GQEAFMAAMMLEEDEVY & $<200$ \\
\hline titin, isoform N2-B (NP_003310/Q8WZ42) & EGILTDRAQIEVTSSFTMLV & $<200$ \\
\hline PITPNB (phosphatidylinositol transfer protein) (CAQ68294/B3KYB6) & HIDIADRSQVEPADYKADED & $<200$ \\
\hline LYPDC1 (AAH40046/Q8IXM0) & QERVDDRAEVEKRLREGEED & $<200$ \\
\hline TMEM64 (transmembrane protein 64) (AAI13829/Q6YI46) & MFYVVHRAOVELNAAIVACE & $<200$ \\
\hline PMS2 (mismatch repair endonuclease) (BAD89425/P54278) & PSDPTDRAEVEKDSGHGSTS & $<200$ \\
\hline
\end{tabular}

"Genbank and Uniprot references are indicated in parenthesis.

${ }^{* *}$ Residues known to be critical for 12G4 binding (25) are in bold and identical residues found in the same position in the DRAQVEM sequence of MISR-II are underlined.

Table 3: Affinity constants $\left(K_{\mathrm{D}}\right)$ of low-fucosylated 3C23K and glycosylated 3C23K-HEK293 for the different human $\mathrm{Fc} \gamma$ receptors

\begin{tabular}{ccc}
\hline & \multicolumn{3}{c}{ Antibody } \\
\hline Receptor & 3C23K & 3C23K-HEK293 \\
\hline Fc $\gamma$ RI/CD64 & $0.1-2.7^{*}$ & $0.2-3.6^{*}$ \\
Fc $\gamma$ RIIa/CD32a & 176 & 182 \\
Fc $\gamma$ RIIbc/CD32bc & 316 & 378 \\
Fc $\gamma$ RIIIa/CD16a & $1-12^{*}$ & $31-164^{*}$ \\
Fc $\gamma$ RIIIb/CD16b & 86 & 378 \\
\hline
\end{tabular}

Affinity constants are expressed as $\mathrm{K}_{\mathrm{D}}$ in $\mathrm{nM} .{ }^{*} \mathrm{~K}_{\mathrm{D} 1}$ and $\mathrm{K}_{\mathrm{D} 2}$ were calculated by using heterogeneous fitting model.

The $\mathrm{K}_{\mathrm{D}}$ values, expressed in $\mathrm{nM}$, were calculated by using a steady-state fitting model, but for Fc $\gamma \mathrm{RI}$ and Fc $\gamma \mathrm{RIIIa}$. Fc $\gamma \mathrm{RI}$ and Fc $\gamma$ RIIIa do not adhere to the one-to-one binding model and fit well using a heterogeneous ligand model (60). The fitting curves and data are given in supplementary data. The $\mathrm{K}_{\mathrm{D}}$ values of $3 \mathrm{C} 23 \mathrm{~K}$ and $3 \mathrm{C} 23 \mathrm{~K}-\mathrm{HEK} 293$ were obtained with the same fitting model, thus allowing comparing the data for each receptor, although the precise binding mechanism has not been elucidated yet and the affinity values reported can vary (60).

\section{Analysis of 3C23K mechanisms of action}

\section{Analysis of COV434-MISRII cell responsiveness to MIS}

Before evaluating the possible mechanisms of action of the $\mathrm{MAb} 3 \mathrm{C} 23 \mathrm{~K}$, clonogenic assays were performed to determine whether the COV434-MISRII cell line is sensitive to MIS, the natural ligand of MISRII, and, thus, to confirm that it is a relevant model. The parental COV434-WT cell line was used as control. MIS reduced the clonogenic survival of both cell lines (Figure 4A). Specifically, the number of clones was decreased by about $25 \%$ with only $0.1 \mathrm{nM}$ MIS and up to $80 \%$ with $50 \mathrm{nM}$ MIS. These results compared favorably with those 
obtained by Masiakos et al. who used $100 \mathrm{nM}$ MIS and different OC cell lines [16]. They also confirmed that both COV434 cell lines contain the machinery required for MIS/MIS receptor signaling and that they respond to MIS even at very low levels of MISRII expression (almost undetectable by FACS in COV434-WT cells [20]). On the other hand, $1 \mu \mathrm{g} / \mathrm{ml} 3 \mathrm{C} 23 \mathrm{~K}$ decreased clonogenic survival only in COV434-MISRII cells by about $35 \%$ compared with untreated cells (Figure 4A), demonstrating that $3 \mathrm{C} 23 \mathrm{~K}$ needs a sufficient MISRII expression level for its activity (the antigenic density in COV434-MISRII cells was $2 \times 10^{4}$ receptors/cell by using Qifikit [20]).

To further confirm that the MIS pathway was functional and potentially activated in COV434-MISRII cells, the level of phosphorylated Smad-1/5 was evaluated following incubation with MIS. Indeed, MIS binds to MISRII that in turn, recruits and interacts with one of at least three candidate type I receptors (ALK2, ALK3 and ALK6) [12]. Subsequently, the relevant type I receptor mediates downstream signaling by phosphorylating Smad-1/5/8 proteins that then binds to the Smad4 coactivator to form one unit that translocates into the nucleus to induce growth inhibition [12]. In COV434-MISRII cells, MIS-dependent Smad signaling could be induced like in NIH-OVCAR3 cells that express endogenous MISRII (Figure 4B).

\section{C23K does not induce apoptosis of COV434-MISRII} cells

The finding that $3 \mathrm{C} 23 \mathrm{~K}-\mathrm{FcKO}$ did not have any in vivo effect (Figure $3 \mathrm{~B}$ ) suggested that $3 \mathrm{C} 23 \mathrm{~K}$ binding to MISRII might not induce a direct anti-proliferative effect in the absence of immune effector cells. Indeed, incubation of COV434-MISRII cells with $50 \mu \mathrm{g} / \mathrm{ml}$ of $3 \mathrm{C} 23 \mathrm{~K}$ or $3 \mathrm{C} 23 \mathrm{~K}-\mathrm{CHO}$ for 24 hours did not induce any significant increase in apoptosis or necrosis compared with an irrelevant antibody (anti-CEA MAb 35A7) (Figure 4C), differently from what reported for MIS [18, 32] and for the mouse 12G4 MAb [20]. This difference with 12G4 could be explained by the different amino acid sequence specifically in the hinge region, as recently reported for rituximab by Könitzer et al. [37].

\section{C23K induces ADCC and ADCP, but no CDC}

Based on the findings that $3 \mathrm{C} 23 \mathrm{~K}-\mathrm{FcKO}$ did not have any in vivo effect (Figure $3 \mathrm{~B}$ ) and that $3 \mathrm{C} 23 \mathrm{~K}$ did not induce apoptosis in vitro (Figure 4B), the potential $3 \mathrm{C} 23 \mathrm{~K}$ Fc-related mechanisms of action were investigated. First, CDC was assessed using a cytotoxicity detection kit based on the measurement of lactate dehydrogenase (LDH) activity released by damaged cells. COV434-MISRII cells were incubated with increasing concentrations of $3 \mathrm{C} 23 \mathrm{~K}$ or $3 \mathrm{C} 23 \mathrm{~K}-\mathrm{CHO}$ (0 to $5,000 \mathrm{ng} / \mathrm{ml})$ in the presence of baby rabbit serum, as a source of complement (1/10 dilution). After 1 hour of incubation at $37^{\circ} \mathrm{C}$, no cell lysis was observed, whatever the treatment (data not shown). Lack of CDC activity in our experimental conditions could be attributed to the too low MISRII antigenic density $\left(2 \times 10^{4}\right.$ receptors/cell [20]) for CDC. Moreover, FACS analysis of the expression of membrane-bound complement regulatory proteins (mCRPs) [38] showed no expression of CD55, but clear expression of CD46 and CD59 (MFI = 6.9 and 16.0 , respectively).

ADCC was first assessed using human NK cells, as standard ADCC effectors cells. $3 \mathrm{C} 23 \mathrm{~K}$ and $3 \mathrm{C} 23 \mathrm{~K}-\mathrm{CHO}$ induced ADCC of COV434-MISRII cells (Figure 4D). The maximal lysis obtained at the highest antibody concentration $(5000 \mathrm{ng} / \mathrm{ml})$ was $56 \%$ with $3 \mathrm{C} 23 \mathrm{~K}$ and $46 \%$ with $3 \mathrm{C} 23 \mathrm{~K}-\mathrm{CHO} ; 50 \%$ of the maximal lysis was
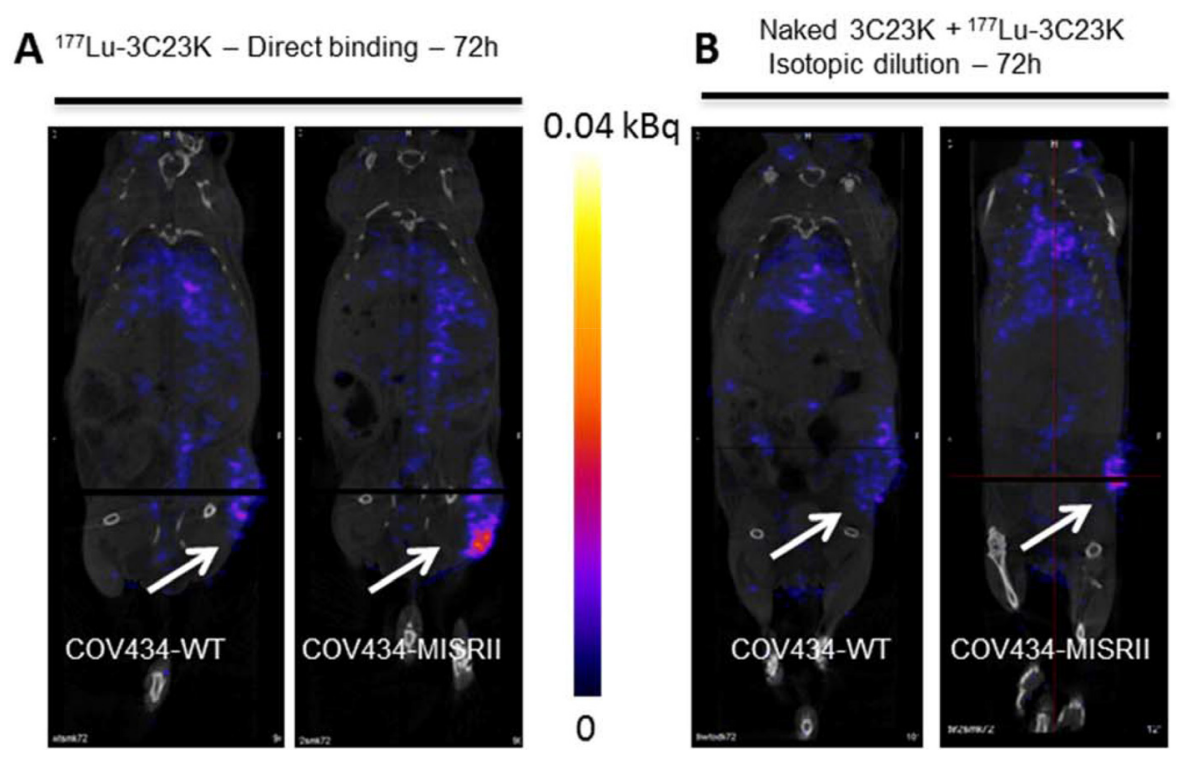

Figure 2: SPECT/CT imaging of COV434-MISRII and COV434-WT cell-derived xenografts in nude mice. Representative images obtained (A) at 72 hours post-i.p. injection of ${ }^{177} \mathrm{Lu}-3 \mathrm{C} 23 \mathrm{~K} 3 \mathrm{~K}$ (direct binding), (B) at 72 hours post-injection of ${ }^{177} \mathrm{Lu}-3 \mathrm{C} 23 \mathrm{~K}$ that was administered 10 minutes after injection of naked 3C23K $(20 \mathrm{mg} / \mathrm{kg})$ (isotopic dilution). 
obtained with $133.35 \mathrm{ng} / \mathrm{ml}$ of $3 \mathrm{C} 23 \mathrm{~K}-\mathrm{CHO}$ and with $2.9 \mathrm{ng} / \mathrm{ml}$ of $3 \mathrm{C} 23 \mathrm{~K}$ (a 46-fold lower concentration).

To perform experiments closer to the in vivo situation, ADCC was then measured using human, cynomolgus monkey and mouse peripheral blood mononuclear cells (PBMC). Human PBMC purified from three different donors heterozygous for the Fc $\gamma$ RIIIa-158 polymorphism induced a clear ADCC at a 20:1 effector to target cells $(\mathrm{E}: \mathrm{T})$ ratio and a MAb concentration of $1000 \mathrm{ng} / \mathrm{ml}$. $3 \mathrm{C} 23 \mathrm{~K}$ was more efficient with up to $24 \%$

A1
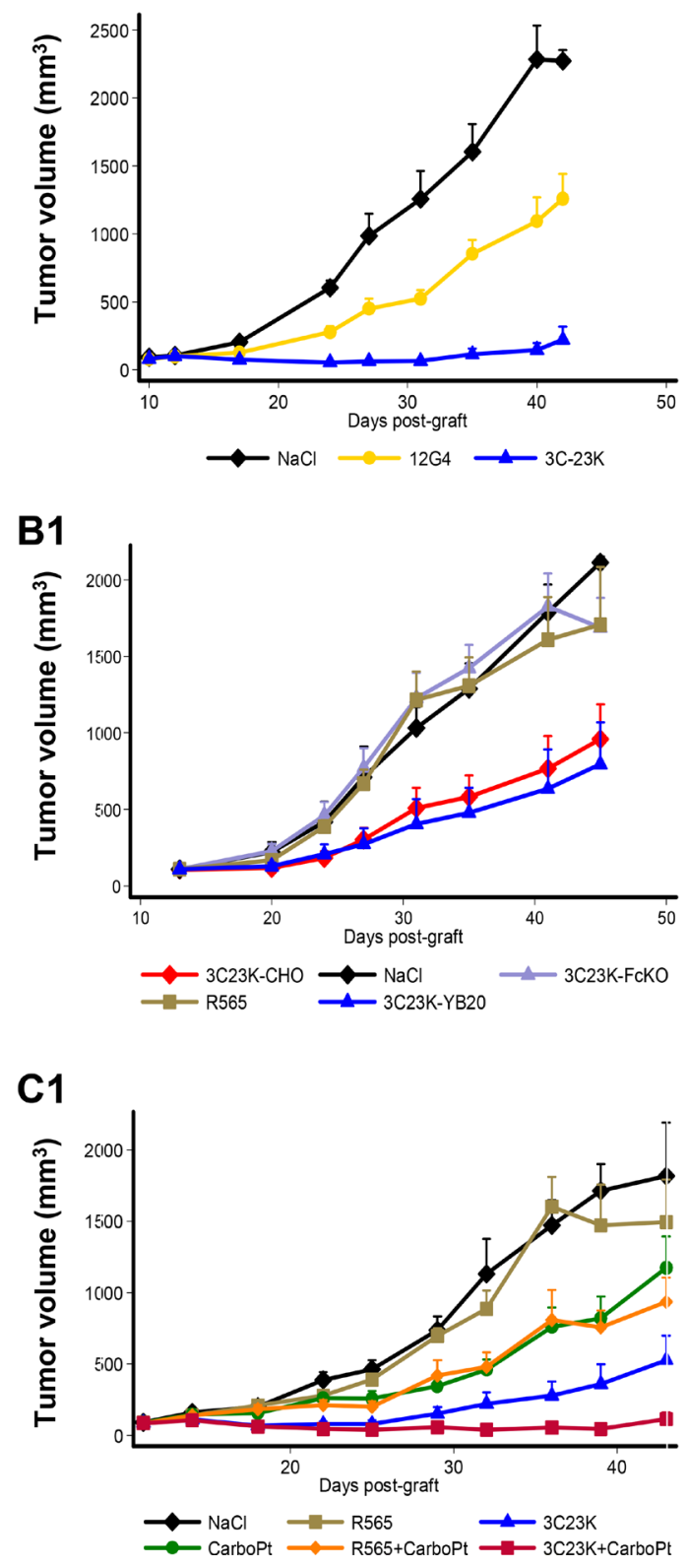

specific lysis compared with $17 \%$ for $3 \mathrm{C} 23 \mathrm{~K}-\mathrm{CHO}$ (Figure 4E). Depending on the experiment, 50\% of maximal lysis was obtained with 2.5- to 4.5-fold lower concentrations of $3 \mathrm{C} 23 \mathrm{~K}$ than $3 \mathrm{C} 23 \mathrm{~K}-\mathrm{CHO}$. Very similar results were obtained with cynomolgus monkey PBMC, but with lower maximum lysis levels (17\% and $9 \%$ for $3 \mathrm{C} 23 \mathrm{~K}$ and $3 \mathrm{C} 23 \mathrm{~K}-\mathrm{CHO}$, respectively) (Figure 4E). ADCC was more difficult to observe using murine PBMC because only one experiment in three gave some results with an $\mathrm{E}: \mathrm{T}$ ratio of 50 and a MAb concentration

A2
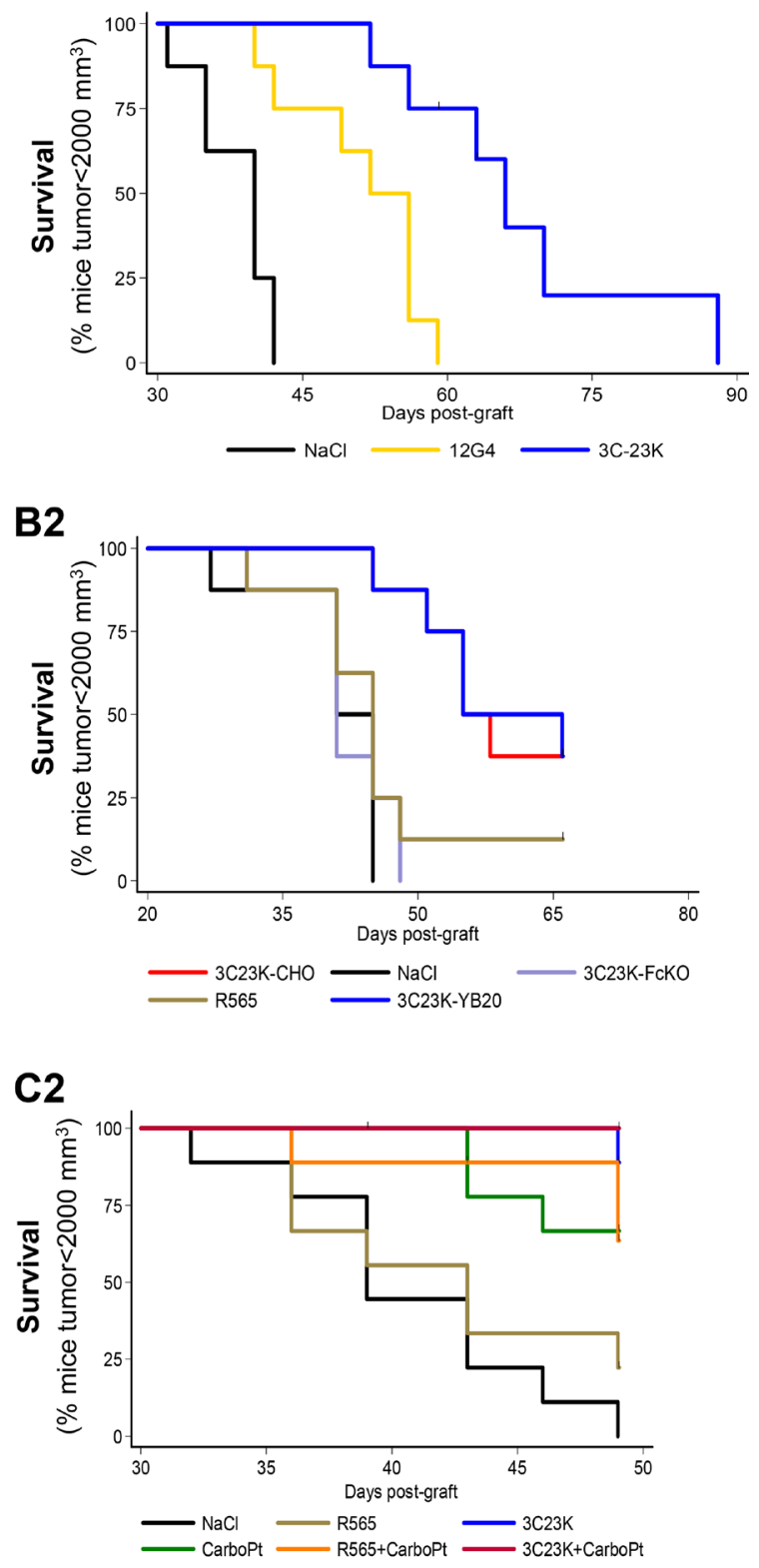

Figure 3: In vivo efficacy of EMABling ${ }^{\circledR} 3 \mathrm{C} 23 \mathrm{~K}$ (low-fucose form) in mice xenografted with COV434- MISRII human ovarian cancer cells (A) Comparison with murine $12 \mathrm{G} 4$ or $\mathrm{NaCl}$, as vehicle (7-8 mice/group). (B) Comparison with $3 \mathrm{C} 23 \mathrm{~K}-\mathrm{CHO}$ (normal fucose form), $3 \mathrm{C} 23 \mathrm{~K}$ mutated in the $\mathrm{Fc}$ domain (no binding to Fc receptors) and the irrelevant R565 antibody (9 mice/group) and (C) Association with $60 \mathrm{mg} / \mathrm{kg}$ carboplatin (CarboPt). Results are presented as (1) tumor growth curves (mean and 95\% CI upper bound) and (2) Kaplan-Meier survival curves (percentage of mice with a tumor volume lower than 2,000 $\mathrm{mm}^{3}$ as a function of time after graft). 
of $30 \mu \mathrm{g} / \mathrm{ml}$ (Figure 4E). With murine PBMC, 3C23K did not show any advantage relative to $3 \mathrm{C} 23 \mathrm{~K}-\mathrm{CHO}$.

The low ADCC level obtained with murine PBMC and the similarity of ADCC level between $3 \mathrm{C} 23 \mathrm{~K}$ and $3 \mathrm{C} 23 \mathrm{~K}-\mathrm{CHO}$ were not in agreement with our in vivo results in mice, suggesting that $\mathrm{ADCC}$ might not be the main mechanism of action. ADCP was thus investigated, as an alternative mechanism of action for $3 \mathrm{C} 23 \mathrm{~K}$. COV434-MISRII cells labeled with the cell tracker CMFDA were incubated with $3 \mathrm{C} 23 \mathrm{~K}$ or an irrelevant antibody (R565) for 30 minutes and then added to human, cynomolgus monkey or murine macrophages for 5, 5 or 3 days, respectively. Afterwards, the number of living COV434-MISRII cells, considered as a representative and easy parameter for assessing ADCP efficacy and for comparison with ADCC, was measured by FACS and expressed as a percentage relative to control (irrelevant antibody) (Figure 4F). In this assay, murine macrophages were even more efficient than human and cynomolgus monkey macrophages with only $10 \%$ of live target cells left after incubation with $100 \mathrm{ng} / \mathrm{ml} \mathrm{3C} 23 \mathrm{~K}$ compared with about $25 \%$ of live cells when using human or cynomolgus monkey macrophages (Figure 4F).

\section{DISCUSSION}

OC has an overall cure rate of less than $40 \%$ and, except for a moderate effect observed with bevacizumab, no significant treatment progress has been made so far. New therapies are, therefore, required to improve OC outcome. Targeted therapies using MAbs have substantially improved the management of many solid tumors and hematologic malignancies [39] and may also be effective in OC. The emergence of new targets, such as sperm protein 17 [40] and MISRII [25], may offer new hope.

In this study, we describe the development and testing of a humanized and glyco-engineered version of the anti-human MISRII mouse MAb 12G4 [25] in order to reduce its immunogenicity and to increase its effector activity, in view of its transfer to the clinic. Using the classical humanization technique based on the transfer of mouse CDRs to the human FRs followed by the MutaGen $^{\text {TM }}$ technology [27, 33] and combining mutations from different variants, we isolated the $3 \mathrm{C} 23 \mathrm{~K} \mathrm{MAb}$ that exhibits the same epitope DRAQVEM and a higher antigen affinity than the parental 12G4 antibody.

Then, $3 \mathrm{C} 23 \mathrm{~K}$ was expressed in $\mathrm{YB} 2 / 0$ cells using the EMABling ${ }^{\circledR}$ technology to increase the antibody interaction with the low/medium affinity Fc $\gamma$ RIIIa receptor that is mainly expressed on NK cells and macrophages [30]. This property is related to the lower expression of the Fut8 gene in rat myeloma YB2/0 cells compared with other commonly used cell lines, such as CHO cells [30]. Two EMABling ${ }^{\circledR}$ MAbs, the anti-RhD roledumab [41] and the anti-CD20 ublituximab [42], are currently in clinical development. Moreover, we [29, 41] and other groups
[43-45] have demonstrated that such improved effector functions are associated with higher therapeutic efficacy in humans, especially in oncology.

As expected, 3C23K-YB2/0 displayed higher binding affinity for Fc $\gamma$ RIIIa receptor than high-fucose content $3 \mathrm{C} 23 \mathrm{~K}$ (Table 3). This enhanced binding to FcyRIIIa receptor gave to $3 \mathrm{C} 23 \mathrm{~K}$ a stronger cytotoxic activity, as measured by ADCC, which was 32-fold higher than that of the same $3 \mathrm{C} 23 \mathrm{~K}$ molecule produced in CHO or HEK293 cells (Figure 4C). One of the potential drawbacks of second generation therapeutic antibodies with enhanced Fc-related mechanisms of action is that their enhanced efficacy on tumor cells could perhaps result in higher toxicity if the target antigen is also expressed in normal tissues, even at low antigenic density. Thus, to assess MISRII expression in normal tissues, we analyzed by qPCR a series of 48 human tissue samples (Supplementary Figure 3). MISRII expression was observed essentially in ovary, which was used as calibrator (relative quantification, $\mathrm{RQ}=1$ ), and, to a lesser extent, in adrenal gland $(R Q=0.486)$, testis $(R Q=0.267)$, penis $(\mathrm{RQ}=0.169)$ and pancreas $(\mathrm{RQ}=0.138)$ (Supplementary Figure 3). This restricted expression profile of MISRII is, thus, well adapted to second generation therapeutic antibodies with enhanced Fc-related mechanisms of action, such as $3 \mathrm{C} 23 \mathrm{~K}$.

3C23K-mediated ADCC could be considered as elevated, on the basis of MISRII antigenic density (about $2 \times 10^{4}$ receptors per cell by Qifikit measurement [20]). However, a recent study on MISRII regulation showed that this receptor clusters at the cell surface [46]. In these clusters, MISRII density is very high and this might promote ADCC. This observation makes of MISRII-3C $23 \mathrm{~K}$ an ideal receptor-MAb couple for OC immunotherapy.

The strong anti-tumor efficacy of $3 \mathrm{C} 23 \mathrm{~K}$ was confirmed in vivo. Intraperitoneal administration of 3C23K significantly delayed the growth of COV434MISRII tumor xenografts and its effect was additive with that of carboplatin (Figure 3A and 3C). The antibody anti-tumor cytotoxic effect was abolished when Fcmutated $3 \mathrm{C} 23 \mathrm{~K}$, which cannot bind to the Fc receptor, was used (Figure 3B).

Taken together, these data suggest that $3 \mathrm{C} 23 \mathrm{~K}$ binding to Fc $\gamma$ RIII plays a major role in promoting ADCC. These results are in agreement with those by Liu et al. [47] using anti-CD20 (in hematologic cancers) or anti-HER2 (in solid tumors) therapeutic antibodies. Specifically, they found that the higher affinity of afucosylated antibodies for Fc $\gamma$ RIIIa, compared with high-fucose antibodies, stimulates the activation of signaling molecules that potentiate $\mathrm{NK}$ cell cytotoxic activity, thus increasing ADCC efficiency [47, 48].

Our in vivo data also highlight a difference between the efficacy of the murine 12G4 MAb and the humanized $3 \mathrm{C} 23 \mathrm{~K} \mathrm{MAb}$ (Figure 3A). This could be attributed to 
C

Apoptosis
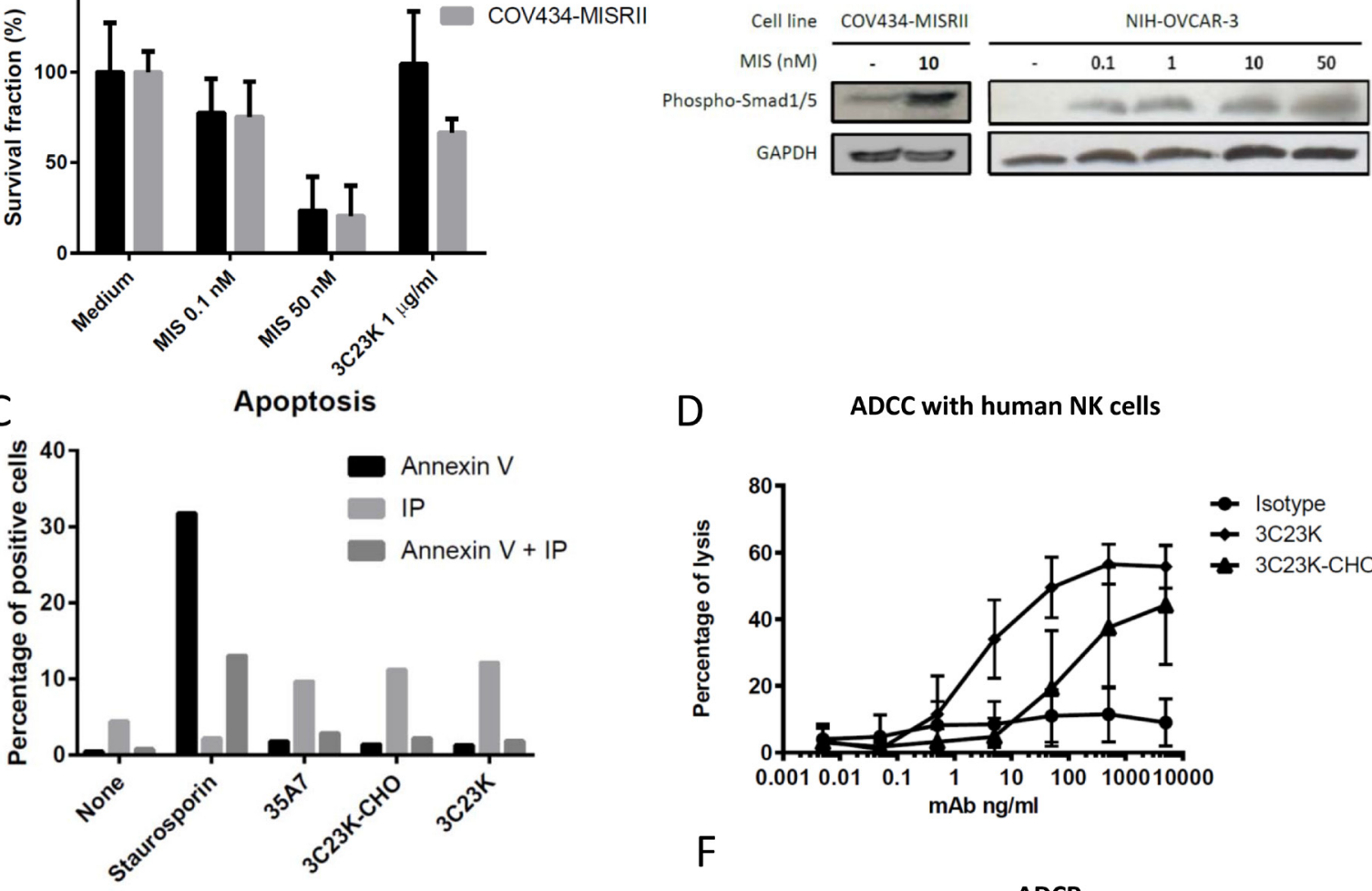

D

ADCC with human NK cells

$E$
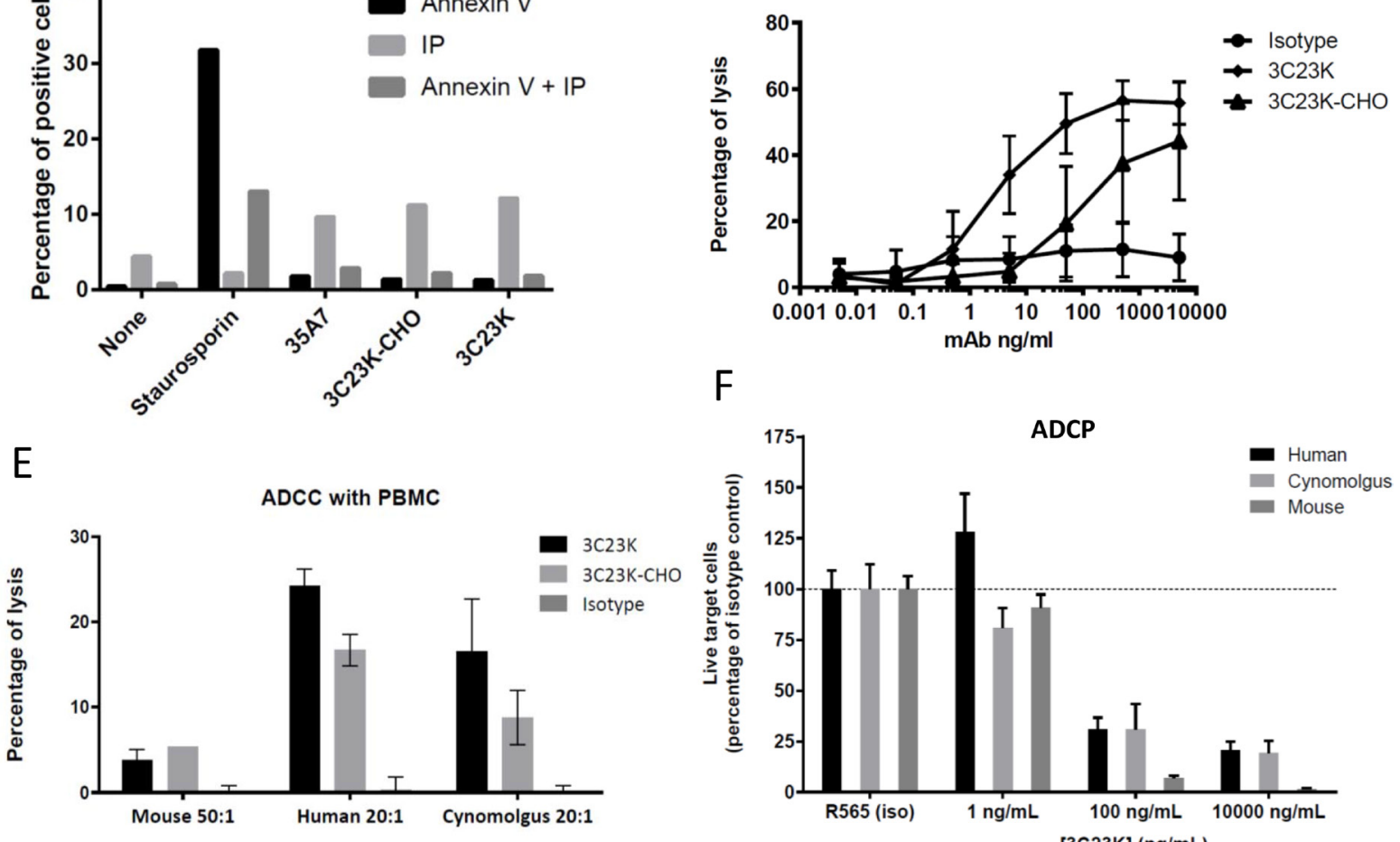

F

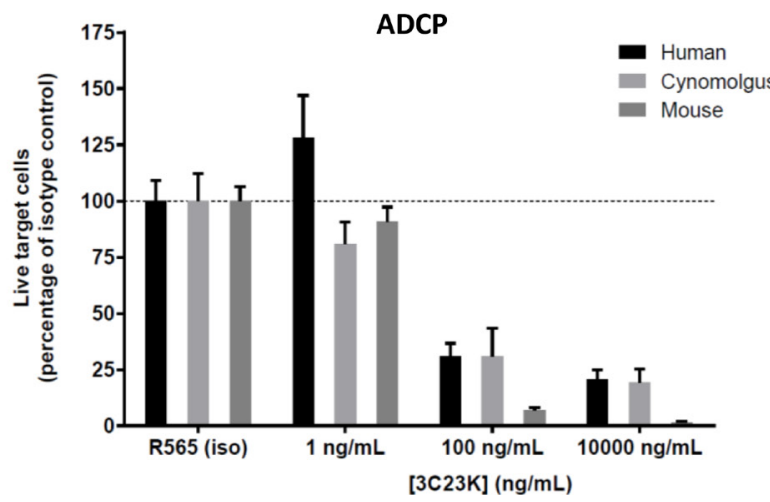

Figure 4: In vitro studies to determine 3C23K mechanisms of action. (A) Clonogenic assay: Clonogenic survival of COV434-WT and COV434-MISRII cells incubated or not (medium) with MIS $(0.1$ or $50 \mathrm{nM})$ or $3 \mathrm{C} 23 \mathrm{~K}(1$ or $100 \mu \mathrm{g} / \mathrm{ml})$. After 15 days of culture in the presence of MIS or 3C23K, colonies were fixed with a methanol/acetic acid solution (3:1), stained with $10 \%$ Giemsa and counted. (B) Smad1/5 phosphorylation: Western blot analysis of serum-deprived (for 48 hours) COV434-MISRII (left panel) or NIH-OVCAR-3 (right panel) cell extracts obtained after incubation or not with MIS $1(0.1,1,10$ or $50 \mathrm{nM}$ ) for 1 hour using anti-phospho-Smad1/5 (Ser463/465) (41D10) rabbit MAb. MIS induced Smad1/5 phosphorylation in MISRII-overexpressing COV434 and NIH-OVCAR3 cells at all the tested concentrations in a dose-dependent manner. (C) Apoptosis: After incubation with $50 \mu \mathrm{g} / \mathrm{ml} \mathrm{MAb}$ (as indicated) or $150 \mathrm{nM}$ staurosporin (positive control) for 24 hours, COV434-MISRII cells were stained using the Annexin V-FITC Apoptosis Detection Kit (Beckman Coulter IM3614). Results of one representative experiment out of four are shown and are expressed as the percentage of cell labeled with Annexin V, propidium iodide (PI) or both. (D and E) ADCC: COV434-MISRII cells were incubated with human NK cells $(\mathrm{E}: \mathrm{T}$ ratio $=10)$ purified from healthy donors' peripheral blood (D) or human, cynomolgus monkey or mouse PBMC (E:T ratio indicated in the figure) (E) and increasing concentrations of antibody $(3 \mathrm{C} 23 \mathrm{~K}, 32 \mathrm{C} 3 \mathrm{~K}-\mathrm{CHO}$ or irrelevant $\mathrm{MAb})$ at $37^{\circ} \mathrm{C}$ for 4 hours. The lysis of target cells was assessed by quantifying the release of lactate dehydrogenase (LDH) by target cells in the supernatant and calculated according to the formula: \% lysis $=[($ ER-SR $) /(100-S R)]-[(N C-S R) /(100-S R)]$, where ER, SR and NC represent the experimental LDH release, the spontaneous LDH release (target cells without NK cells and without antibody) and the natural cytotoxicity (target cells + NK cells without antibody), respectively. (F) ADPC: COV434-MISRII target cells labeled with the CMFDA dye (CellTracker ${ }^{\mathrm{rm}}$ Green, Life Technologies) and pre-incubated with increasing concentrations of antibody ( $3 \mathrm{C} 23 \mathrm{~K}$ or irrelevant $\mathrm{MAb}$ ) at room temperature for 30 minutes were mixed (10:1 $\mathrm{E}: \mathrm{T}$ ratio) with macrophages derived from monocytes obtained from human or cynomolgus monkey PBMC or mouse bone marrow. Living target cells were quantified by flow cytometry after 3 (human and cynomolgus monkey macrophages) or 5 days (mouse macrophages). Results are expressed as percentages relative to the corresponding isotype control. 
the major differences between human and mouse FcR systems for specific IgG subclasses. It has been shown that differently from other mouse Fc $\gamma$ Rs, mouse Fc $\gamma$ RIV has a distinct IgG subclass specificity with no affinity for mouse IgG1 or IgG3 and high-affinity for mouse IgG2a and IgG2b. Conversely, Fc $\gamma$ RIII is a low-affinity receptor for mouse IgG1, IgG2a and IgG2b (for review [34]). In parallel, it was clearly demonstrated using a panel of antiEGFR MAbs and A431 cells that human IgG1 are the most potent in inducing mouse PMN-mediated ADCC compared with murine IgG1 or IgG2 [35].

ADCC is considered the main immune-related mechanism of action of therapeutic MAbs, as reported at the preclinical [49] and clinical levels [50, 51] for different anti-carcinoma antibodies, including cetuximab and trastuzumab. After confirmation of the high ADCC potential of $3 \mathrm{C} 23 \mathrm{~K}$ with human $\mathrm{NK}$ cells $(50 \%$ maximal lysis obtained with $2.9 \mathrm{ng} / \mathrm{ml}$ of $3 \mathrm{C} 23 \mathrm{~K}$ compared with $133.35 \mathrm{ng} / \mathrm{ml}$ of 3C23K-CHO; Figure 4), we investigated its ADCC activity with PBMC. 3C23K induced high ADCC with human and cynomolgus monkey PBMC and very limited ADCC with murine PBMC (Figure 4). As this was not in agreement with our in vivo results, we investigated ADCP and found that it was very high with $3 \mathrm{C} 23 \mathrm{~K}$ and murine macrophages. This can be explained by the fact that human IgG1 exhibit the strongest binding to murine FcyRIV expressed on murine macrophages [52] and ADCP certainly contributes to $3 \mathrm{C} 23 \mathrm{~K}$ in vivo efficacy and might compensate at least partially the lack of activation of murine NK cells (Figure 3). Overall, these data strongly suggest that in vivo pre-clinical experiments underestimate the possible $3 \mathrm{C} 23 \mathrm{~K}$ efficacy in the clinic.

Besides efficacy, toxicity is an important issue in the development of a new drug. As $3 \mathrm{C} 23 \mathrm{~K}$ does not bind to mouse MISRII, our experiments in mice gave us no clue on its possible toxicity towards normal tissues. However, as a first step towards clinical trials, we performed regulatory toxicological studies in cynomolgus monkeys and $3 \mathrm{C} 23 \mathrm{~K}$ did not elicit any sign of toxicity with no observed adverse effect level (NOAEL) at doses $\geq 300 \mathrm{mg} / \mathrm{kg}$ [53].

In conclusion, on the basis of the previous characterization of the mouse $12 \mathrm{G} 4 \mathrm{MAb}[20,25]$ and the present data, the anti-MISRII MAb $3 \mathrm{C} 23 \mathrm{~K}$ appears to be a promising new EMABling ${ }^{\circledR}$ therapeutic candidate for OC treatment. In 2016, a phase I clinical trial (NCT02978755) was initiated with 3C23K (now named GM-102) in gynecological cancers.

\section{MATERIALS AND METHODS}

\section{Humanization of the murine MAb 12G4}

$12 \mathrm{G} 4$ variable regions were amplified from total RNA by using the 5' RACE kit (Invitrogen). The variable regions of both chains were cloned into the TOPO TA cloning vector (Invitrogen) and were confirmed by sequencing (MWG). The human acceptor FRs were identified according to Pelat [54]. Briefly, the mouse sequences of the heavy and light chain Fv fragments were used for alignment to human germline sequences in the IMGT database (www.imgt.org). Based on these alignments, amino acid differences at specific positions between the human and murine FRs were detected. The properties of these residues (involvement in disulfide bridges or CDR flanking regions) were analyzed manually with the help of a "collier de perles" representation [31] and led to the construction of FRs for grafting the $12 \mathrm{G} 4$ CDRs of the heavy and light chains.

\section{Affinity maturation of humanized 12G4 (h12G4)}

Based on the variable regions determined previously, 12G4 and h12G4 were reformatted as single chain $\mathrm{Fv}(\mathrm{scFv})$. The $\mathrm{VH}$ and $\mathrm{VL}$ domains were assembled by overlap PCR with an appropriate linker sequence [(GGGGS)3] and inserted in the pMG72 vector (Millegen). The humanized version of the $\mathrm{scFv}$ anti-MISRII antibody was used as template to build four libraries with MutaGen ${ }^{\mathrm{TM}}$ following the previously described procedure [27] and using different experimental conditions and human polymerases. The four libraries were mixed and rescued using the helper phage M13K07 (New England Biolabs). After overnight expression, phage-scFv particles were purified by PEG precipitation and titrated by infecting XL1-Blue cells (Stratagene).

The recombinant MISRII-Fc protein was produced using the FreeStyle ${ }^{\mathrm{TM}}$ MAX CHO Expression System (Invitrogen) and purified on protein A. For phage library panning, recombinant MISRII-Fc was immobilized onto Maxisorb (Nunc) at two concentrations: $1 \mu \mathrm{g}$ (rounds 1-4) and $0.5 \mu \mathrm{g}$ (rounds 5-6) per well. An aliquot of the scFV-phage particles in PBST/5\% skimmed milk was added to the coated wells that were pre-blocked with $5 \%$ skimmed milk. After 2 hours of incubation at $37^{\circ} \mathrm{C}$ and several washes, bound scFv-phage particles were eluted by adding exponentially growing XL1-Blue bacteria. Infected XL1-Blue cells were then plated on Petri dishes and grown overnight, before being transferred to $2 \times$ YT medium/ glycerol and used for the next selection step.

After phage panning, the pairs of $\mathrm{VL}$ and $\mathrm{VH}$ domains of the selected variants (mouse and humanized anti-MSRII antibodies) were reformatted as Fab fragments. They were subcloned in the bicistronic bacterial expression vector pMG92 to introduce a V5 tag (Invitrogen) and a His6 tag, both at the C-terminus of the VH-CH1 chain. The Fab fragments were expressed overnight at $30^{\circ} \mathrm{C}$ in $E$. coli $\mathrm{HB} 2151$ cells by adding $0.5 \mathrm{mM}$ IPTG. The Fab fragments were then purified by one-step chromatography with Ni-NTA resin (Qiagen) and, after dialysis against PBS, were kept at $4^{\circ} \mathrm{C}$ until use.

\section{Binding characterization of the anti-MISRII antibodies}

The binding of the different antibody clones to MISRII was evaluated by ELISA assay. The purified Fab 
fragments were evaluated with a similar ELISA assay at various concentrations (from $10 \mu \mathrm{g} / \mathrm{ml}$ to $156 \mathrm{ng} / \mathrm{ml}$ ). Bound Fab fragments were detected by adding the HRPlabeled anti-V5 antibody (Invitrogen). The mouse (12G4) and humanized (h12G4) anti-MISRII antibodies in the IgG format were also compared in an ELISA assay using, respectively, anti-mouse IgG (HRP-conjugated) (Cell Signaling) and anti-human F(ab') ${ }_{2}$ fragment (HRPconjugated) (Interchim) antibodies.

Antigen recognition was also monitored by flow cytometry using $2 \times 10^{5}$ COV434-MISRII cells. Cells were incubated with $100 \mu$ l of chimeric or humanized $12 \mathrm{G} 4$ at different concentrations ( 0 to $10 \mu \mathrm{g} / \mathrm{ml}$, final concentration) [20]. After washing, cells were incubated with $100 \mu \mathrm{l}(1: 100)$ of a goat anti-human FITC-labeled antibody (Beckman Coulter). Cells were finally washed and analyzed with a flow cytometer (Beckman Coulter).

\section{Cloning of chimeric 12G4, humanized 12G4 and 3C23K}

Chimeric 12G4 (ch12G4) was constructed and expressed as described previously [30]. Briefly, the VL and VH DNA sequences were subcloned sequentially into the polycistronic CHK622-08 vector that contains the promoter, Kozak sequence and the sequences of the human Kappa/IgG1 constant regions.

The DNA sequences coding for humanized 12G4 (h12G4) VL and VH were synthesized using Genscript and then cloned in CHK622-08 by digestion and ligation as described above, resulting in the HK622-18 vector. The DNA sequences coding for affinity-matured 3C23K $\mathrm{VL}$ and $\mathrm{VH}$ were obtained by directed mutagenesis of the phage clone 3C23 to introduce the VL E68K mutation. Signal peptides were added by PCR assembly using the humanized variable regions of h12G4 as template and then cloned in HK622-18, as described above. The resulting vector that expresses the humanized and affinity-matured 3C23K antibody was called HK622-18 MAO 3C23K.

\section{Production and purification of ch12G4, h12G4 and 3C23K}

The different molecules were stably expressed, as previously described [30]. CHO-S, HEK293 or YB2/0 cells were stably transfected with the appropriate linearized expression vectors. Ch12G4, h12G4 and 3C23K antibodies were produced in YB2/0 cell using EMS (Invitrogen), 5\% Ultra-low IgG fetal calf serum (FCS) (PAA) and $0.5 \mathrm{~g} / 1 \mathrm{G} 418$ for 5 to 7 days. 3C23K-CHO-S was produced in CHO-S cells using ProCHO4 (Lonza), $4 \mathrm{mM}$ glutamine and $1 \mathrm{~g} / \mathrm{l} \mathrm{G} 418$ for 7 days.

MAbs were purified from culture supernatants by affinity chromatography using protein A sepharose (GEHealthcare). The levels of aggregates and endotoxins were determined by gel filtration on Superdex HR/200 (GEHealthcare) and by LAL testing, respectively. Antibody quality and purity were monitored by SDS-PAGE and Coomassie staining. In addition, the glycosylation patterns and core fucose percentage of each purified antibody were determined by high performance capillary electrophoresis laser induced fluorescence (HPCE-Lif) [55].

\section{Epitope mapping}

Epitope mapping for $3 \mathrm{C} 23 \mathrm{~K}$ was performed by peptide array using the EpiFlag $^{\circledR}$ methodology (Innobiochips). Thirteen 20 -amino acid peptides covering the 132 first C-terminal amino acids of MISRII were synthesized by solid phase peptide synthesis (Intavis AG). A peptide containing the epitope DRAQVEM in the central position was used as control.

Each peptide was characterized by RP-HPLC and MALDI-TOF MS and lyophilized. Peptide arrays were prepared by dissolving peptides at $0.1 \mathrm{mM}$ in $0.01 \mathrm{M}$ PBS pH 7.4 and printing them on amine-modified glass slides (Arrayit). Microarrays were then saturated with PBS-M (PBS, 0.05\% Tween 20, 2.5\% non-fat milk). After washes, slides were incubated with $20 \mu \mathrm{g} / \mathrm{ml} 3 \mathrm{C} 23 \mathrm{~K}$ in PBS-M at $4{ }^{\circ} \mathrm{C}$ overnight. Bound antibodies were detected by adding a fluorescently labeled polyclonal anti-human IgG antibody (Abcam) at room temperature for 1 hour. Bound antibodies were detected using a TECAN LS Reloaded laser scanner (Tecan). Data were extracted and analyzed using the Array-Pro ${ }^{\circledR}$ Analyzer software. The antibody binding potencies to the different peptides were compared using the Student $t$-test and the Statgraphics Centurion XV V15.2.06 (StatPoint, Inc) software. Differences were considered as statistically significant when $p<0.05$.

\section{SPR analysis}

SPR analyses were performed on a Bia3000 or T200 apparatus at $25^{\circ} \mathrm{C}$ in $\mathrm{HBS}-\mathrm{EP}$ (GE Healthcare). For affinity measurements, MISRII was covalently immobilized (1000 RU) on a CM5 sensor chip using EDC/NHS activation, according to the manufacturer's instructions (GE Healthcare). Different concentrations (0.5-128 nM) of $12 \mathrm{G} 4$ or $3 \mathrm{C} 23 \mathrm{~K}$ were injected on immobilized receptor during 180 seconds. After 400 seconds of dissociation in running buffer, the sensor chip was regenerated using Gly-HCl pH 1.7. The $\mathrm{K}_{\mathrm{D}}$ values, taking into account affinity and avidity, were calculated using a Langmuir 1:1 fitting model (BiaEvaluation3.2, GE Healthcare). Antibody-Fc $\gamma \mathrm{R}$ measurements were performed by singlecycle titration at $100 \mu \mathrm{l} / \mathrm{min}$ on Fc $\gamma \mathrm{R}$ (Sigma) captured on anti-His (R\&D Systems) covalently immobilized at 4000-5000 RU level. The gamma receptor was injected at $20 \mathrm{nM}$ during 60 seconds and five increasing antibody concentrations (supplementary data) were injected (injection time $=60$ seconds). After a dissociation step of 600 seconds in running buffer, sensor surfaces were regenerated using $5 \mu \mathrm{l}$ of Glycine- $\mathrm{HCl} \mathrm{pH}$ 1.7. Kinetic parameters were evaluated from the sensorgrams using a heterogeneous Ligand or steady-state fitting models on the T200evaluation software 3.0 (GE healthcare). All sensorgrams were corrected by subtracting the low signal from the control reference surface (without any 
immobilized protein) and buffer blank injections before fitting evaluation.

\section{Molecular modeling of anti-MISRII antibodies}

All algorithms used for antibody modeling were extracted from the Discovery studio V3.1 software (Accelrys software Inc). The Fab structure of ch12G4 and h12G4 were modeled with a sequence homology approach using MODELER [56]. The best homologous templates were identified by BLAST search against a sequence database of known antibody 3D structures (extracted from the PDB database). The following PDB structures were the templates selected to build the initial model: i) 2OSL for the light and heavy chains of ch12G4; ii) 3EO9 and 2EH7 for the light and heavy chains of h12G4; and iii) 3E09 for the interface. CDR loops were specifically rebuilt and refined using the LOOPER algorithm.70. Starting from the h12G4 model, the $3 \mathrm{C} 23 \mathrm{~K}$ model was built by replacing the four mutated residues generated by the maturation affinity process: I47T, S49P, E54K in the VL and Q3R in the VH. The conformation of the mutated residues and of the surrounding residues that lie within a $5 \AA$ cutoff radius was optimized using the MODELER algorithm. The three models were superimposed based on their sequence alignment, and the main chain atom rmsd calculated using the 3DMA program. The electrostatic potential of the three antibodies was calculated using Delphi, a program that solves the Poisson-Boltzmann equation on a cubical lattice using the finite-difference technique [57].

\section{Cell lines and cell culture}

The human GCT cell line COV434 [58], a kind gift from Peter I. Schrier (Department of Clinical Oncology, Leiden University Medical Center), was called COV434WT in the present work. The COV434-MISRII cell line, a COV434-WT clone transfected with the cDNA encoding full-length human MISRII in the pCMV6 plasmid to stably express MISRII, was described by Kersual et al. [20]. Cells were grown in DMEM F12 medium containing $10 \%$ heat-inactivated fetal bovine serum (FBS), $0.1 \mathrm{mg} / \mathrm{ml}$ streptomycin, $0.1 \mathrm{IU} / \mathrm{ml}$ penicillin and $0.25 \mathrm{mg} / \mathrm{ml}$ amphotericin B. COV434-MISRII cells were supplemented with $0.33 \mathrm{mg} / \mathrm{ml}$ geneticin. Cells were grown at $37^{\circ} \mathrm{C}$ in a humidified atmosphere with $5 \%$ $\mathrm{CO}_{2}$ and medium was replaced twice a week. Cells were harvested with $0.5 \mathrm{mg} / \mathrm{ml}$ trypsin $/ 0.2 \mathrm{mg} / \mathrm{ml}$ EDTA. All culture media and supplements were purchased from Life Technologies, Inc. (Gibco BRL).

\section{Antibodies}

The murine anti-MISRII MAb 12G4 was described by Salhi et al. and Kersual et al. [20, 25]. Anti-idiotype factor VIII chimeric IgG1 R565 EMABling ${ }^{\circledR}$ MAb and antiCEA MAb 35A7 [20] were used as irrelevant antibodies.

\section{Normal tissues MISRII expression analysis by qPCR}

For normal tissue MISRII expression studies, TissueScan Normal Tissues qPCR Arrays (HMRT102, OriGene Technologies) were probed for MISRII (Mix Hs01086650_g1 Applied Biosystems) and GAPDH (Mix 4310844e Applied Biosystems) expression in triplicate on a Real Time PCR thermal cycler (Model and Company). Cycle threshold $(\mathrm{Ct})$ levels are inversely proportional to the amount of target nucleic acid in the sample. An ovary genomic sample was used as internal calibrator. MISRII relative quantification (RQ) was expressed as $2^{-\Delta \Delta \mathrm{Ct}}$ where $\Delta \Delta \mathrm{Ct}=(\Delta \mathrm{Ct}$ sample $-\Delta \mathrm{Ct}$ internal calibrator $)$ and $\Delta \mathrm{Ct}=$ (Ct MISRII gene - Ct GAPDH endogenous control).

\section{Clonogenic survival}

COV434-WT and COV434-MISRII cells were plated in 6-well/plates (200 cells per well) that had been pre-coated with poly-ornithine at $37^{\circ} \mathrm{C}$ for 2 hours. From the next day, cells were cultured in the presence of $0.1 \mathrm{nM}$ or $50 \mathrm{nM}$ MIS (Origene, USA) for 15 days. At day 15 , colonies were fixed with a methanol/acetic acid solution (3:1), stained with 10\% Giemsa and counted. Two independent clonogenic assays were performed. In the second experiment, COV434-WT and COV434-MISRII cells were plated at 400 and 200 cells per well, respectively.

\section{MIS pathway analysis}

Cells were pre-treated by incubation in serum-free DMEM medium for 48 hours, followed by stimulation with MIS $(0.1,1,10$ or $50 \mathrm{nM})$ at $37^{\circ} \mathrm{C}$ for 1 hour. To obtain whole cell lysates, cells were harvested, washed twice with ice-cold PBS and lysed in lysis buffer $(20 \mathrm{mM}$ Tris- $\mathrm{HCl}, \mathrm{pH} 7.5,150 \mathrm{mM} \mathrm{NaCl}, 1 \mathrm{mM} \mathrm{Na} \mathrm{N}_{2}$ EDTA, $1 \mathrm{mM}$ EGTA, 1\% Triton and complete protease inhibitor cocktail). Equal amounts of proteins (30 mg) were separated by $10 \%$ SDS-PAGE in non-reducing conditions. Proteins were transferred to PVDF membranes (Bio-Rad) by electroblotting. Membranes were blocked in 5\% non-fat milk in TBS-T buffer and probed with the anti-phosphoSmad 1/5 MAb (1:1,000; Cell Signaling) at $4^{\circ} \mathrm{C}$ overnight. After washes, membranes were incubated with the antirabbit IgG HRP secondary antibody (1:10,000; Sigma) at room temperature for 1 hour. Proteins were visualized by enhanced chemiluminescence (ECL plus Western Blotting Detection System; Amersham Biosciences).

\section{Apoptosis assay}

Approximately 350,000 cells were seeded in 6-well/ plates and incubated or not with $50 \mu \mathrm{g} / \mathrm{ml}$ MAb, $20 \mathrm{nM}$ MIS or $150 \mathrm{nM}$ staurosporin, as positive control, for $24 \mathrm{~h}$ and then stained using the annexin V-FITC Apoptosis Detection 
Kit (Beckman Coulter IM3614). Both adherent and detached cells were collected and centrifuged at 1,000 rpm for 5 minutes. After washing with PBS, cells were stained with $130 \mu \mathrm{l}$ of a mix containing $10 \mu \mathrm{l}$ FITC-labeled annexin $\mathrm{V}$ and $20 \mu \mathrm{l}$ propidium iodide (PI) in $100 \mu \mathrm{l}$ annexin buffer on ice in the dark for 15 minutes. After addition of $400 \mu \mathrm{l}$ annexin buffer, cells were analyzed by flow cytometry within 30 minutes and data analyses performed using the Kaluza Flow Analysis software (Beckman Coulter).

\section{ADCC assays}

Human NK effectors cells from peripheral blood of healthy donors were purified by negative depletion (NK Cell Isolation Kit, Miltenyi Biotech). COV434-MISRII cells $(30,000$ cells/well of a 96-well flat bottom plate) were incubated with NK cells and increasing antibody concentrations $(3 \mathrm{C} 23 \mathrm{~K}, 32 \mathrm{C} 3 \mathrm{~K}-\mathrm{CHO}$ or irrelevant $\mathrm{MAb}$ ) at $37^{\circ} \mathrm{C}$ for 4 hours. After incubation, supernatant was removed and lysis was measured by quantifying the amount of lactate dehydrogenase (LDH) released by target cells in the supernatant (Cytotoxicity Detection Kit LDH, Roche Diagnostic). The lysis percentage was calculated according to the formula: \% lysis $=[($ ER-SR $) /(100-S R)]-$ $[(\mathrm{NC}-\mathrm{SR}) /(100-\mathrm{SR})]$ where ER, SR and NC represent the experimental LDH release, the spontaneous LDH release (target cells without NK cells and without antibody) and the natural cytotoxicity (target cells + NK cells without antibody), respectively.

PBMC used as effectors cells were of human, cynomolgus monkey and mouse origin. Human PBMC were from three different donors who were heterozygous for the FCGR3A-158 polymorphism. Blood samples were purchased from Etablissement Français du Sang (Nantes, France) and PBMC were isolated using a standard Ficoll procedure. Cynomolgus monkey PBMC were directly purchased from CytoxLab (Evreux, France) and were isolated from blood samples of individual cynomolgus monkeys using a standard Ficoll procedure. Human and cynomolgus monkey PBMC were frozen in FBS with 10\% DMSO and stored in liquid nitrogen until use. Murine PBMC isolated from C57BL/6 mice were directly purchased frozen from AllCells (Alameda, CA, USA). ${ }^{51} \mathrm{Cr}$-labeled COV434-MISRII cells (1,500 cells/ well) were incubated with PBMC and increasing antibody concentrations $(3 \mathrm{C} 23 \mathrm{~K}, 32 \mathrm{C} 3 \mathrm{~K}-\mathrm{CHO}$ or irrelevant $\mathrm{MAb})$ at $37^{\circ} \mathrm{C}$ for 4 hours. Target cell lysis was measured by supernatant gamma counting. The lysis percentage was calculated according to the formula: $\%$ lysis $=\left[\left(\mathrm{CPM}_{\mathrm{X}}{ }^{-}\right.\right.$ $\left.\mathrm{CPM}_{\text {spontaneous }}\right) /\left(\mathrm{CMP}_{\text {maximum }}-\mathrm{CPM}_{\text {spontaneous }}\right] \times 100$ where $\mathrm{X}$, spontaneous and maximum represent the experimental ${ }^{51} \mathrm{Cr}$ release, the spontaneous ${ }^{51} \mathrm{Cr}$ release (target cells without PBMC and without antibody) and the maximum ${ }^{51} \mathrm{Cr}$ release (target cells alone in $0.75 \%$ triton $\mathrm{X}-100$ ), respectively.

\section{ADCP assay}

Monocytes were isolated from adult human or cynomolgus monkey blood samples purchased from Etablissement Français du Sang (Nantes, France) or CytoxLab (Evreux, France), respectively. PBMC were isolated using a standard Ficoll procedure and then plated in non-coated plates with RPMI alone at $37^{\circ} \mathrm{C}$ for 1 hour to allow the adhesion of monocytes to the plastic. Wells were then washed 3 times with $1 \mathrm{ml}$ RPMI/10\% FBS to eliminate non-adherent cells. After 6 to 8 days of culture in RPMI with $10 \%$ FBS and $50 \mathrm{ng} / \mathrm{ml}$ human M-CSF (216MC, R\&D Systems, USA) (medium renewed at day 3-4), macrophages were detached by incubation on ice with ice-cold PBS containing EDTA (4 to $10 \mathrm{mM}$, depending on the adhesion strength) for 10-15 minutes, counted and used for ADCP assays. Frozen macrophages differentiated from monocytes isolated from the bone marrow of C57BL/6 mice were purchased from ScienceCell (San Diego, CA, USA). Macrophages were thawed following the supplier's instructions, resuspended in the specific macrophage culture medium (MaM, ScienceCell) and allowed recovering overnight before ADCP assay.

COV434-MISRII target cells (T) were extemporaneously labeled with the CMFDA dye (CellTracker $^{\mathrm{TM}}$ Green, Life Technologies) following the manufacturer's instructions and pre-incubated with increasing concentrations of antibody (3C23K or irrelevant $\mathrm{MAb}$ ) in $\mathrm{RPMI} / 10 \% \mathrm{FBS}$ at room temperature for 30 minutes before mixing with macrophages (effector cells: E) at a 10:1 E:T ratio. Alive target cells were detected by flow cytometry after 3 or 5 days incubation with human, cynomolgus monkey or mouse macrophages, respectively. Results were expressed as percentage of living cells relative to the isotype control.

\section{In vivo studies using OC xenografts}

All animal experiments were performed in compliance with the guidelines of the French government and the regulations of the Institut National de la Santé et de la Recherche Médicale for experimental animal studies (agreement B34-172-27).

For all the in vivo experiments, female Swiss or athymic nude mice (6-8 week-old) (Harlan Laboratories, St Isle, France) were subcutaneously (s.c.) grafted on the right flank with $7.10^{6}$ human COV434-MISRII cells [20] in BD Matrigel (ratio 1:1) in a volume of $150 \mu$ lat day 0 (D0). Mice were randomized when tumor volume was 60-150 $\mathrm{mm}^{3}$ at D12-D13 ( $n=7-8$ mice/group, for experiment A and $n=9$ mice/group for experiments $\mathrm{B}$ and C). Treatments were all administered by intraperitoneal (i.p.) injection.

For experiment $\mathrm{A}, 3 \mathrm{C} 23 \mathrm{~K}, 12 \mathrm{G} 4$ or vehicle $(\mathrm{NaCl})$ were injected i.p. twice a week for 6 weeks (18 injections in total) at about $10 \mathrm{mg} / \mathrm{kg} /$ injection, Q2-3D18. For experiment $\mathrm{B}, 3 \mathrm{C} 23 \mathrm{~K}$ (anti-MISRII MAb produced in YB2/0 cells), 
3C23K-CHO, 3C23K-FcKO, the irrelevant R565 MAb or vehicle $(\mathrm{NaCl})$ were used. The treatment schedule was the same for all groups: $10 \mathrm{mg} / \mathrm{kg}$ in $200 \mu \mathrm{L}$, one i.p. injection/ week for 4 weeks (Q7D4). In experiment C, 3C23K or the irrelevant antibody R565 was administered twice a week for 6 weeks (12 i.p. injections in total) at about $10 \mathrm{mg} /$ $\mathrm{kg}$ /injection, Q3-4D12. Carboplatin was administered once a week for 4 weeks (four i.p. injections in total) at the previously determined suboptimal dose of $60 \mathrm{mg} / \mathrm{kg} /$ injection, Q7D4. Carboplatin was evaluated alone (Q7D4) or combined with 3C23K (carboplatin Q7D4 + 3C23K Q34D12) or with the irrelevant antibody R565 (carboplatin Q7D4 + R565 Q3-4D12).

In all experiments, tumor dimensions were measured once a week with a caliper and volumes calculated using the formula: $\mathrm{D}_{1} \times \mathrm{D}_{2} \times \mathrm{D}_{3} / 2$. Tumor progression was assessed using the formula [(final volume) - (initial volume)]/(initial volume). Results were also expressed with an adapted Kaplan-Meier survival curve, using the time needed for a tumor to reach the volume of $2,000 \mathrm{~mm}^{3}$. The median survival was defined as the time when $50 \%$ of mice had a tumor of $2,000 \mathrm{~mm}^{3}$.

\section{Statistical analysis}

A linear mixed regression model was used to determine the relationship between tumor growth and days post-graft. The fixed part of the model included variables corresponding to the number of days post-graft and the different groups. Interaction terms were built into the model. Random intercept and random slope were included to take into account the time effect. The model coefficients were estimated by maximum likelihood and considered significant at the 0.05 level. Survival rates were estimated from the xenograft date until the date when the tumor reached the volume of 2,000 $\mathrm{mm}^{3}$ using the KaplanMeier method. Median survival was presented with $95 \%$ confidence intervals. Survival curves were compared using the log-rank test. Statistical analyses were performed using the STATA 11.0 software.

\section{SPECT-CT imaging}

\section{Production of ${ }^{177} \mathrm{Lu}$-labeled 3 C23K}

The MAb $3 \mathrm{C} 23 \mathrm{~K}$ was first conjugated with p-SCNbenzyl-DOTA, as described by Repetto-Llamazares et al. [59] and then labeled with $200 \mathrm{MBq} / \mathrm{mg}{ }^{177} \mathrm{Lu} .{ }^{177} \mathrm{LuCl}_{3}$ was obtained from Perkin Elmer at a volumic activity of $370 \mathrm{MBq}$ in $8 \mu \mathrm{L}$ of $0.05 \mathrm{M} \mathrm{HCl}$ and at a specific activity $>740 \mathrm{~GB}$ q/ mg. Radiochemical purity was $>97 \%$ and radionuclidic purity $>99.94 \%$. 3C $23 \mathrm{~K}$ was labeled with ${ }^{177} \mathrm{Lu}$ at a specific activity of $222 \mathrm{MBq} / \mathrm{mg}$. Typically, $43 \mu \mathrm{l}$ of $7.7 \mathrm{mg} / \mathrm{ml}$ DOTA-conjugated MAb were mixed with $40 \mu \mathrm{l}$ of $0.25 \mathrm{M}$ NH4OAc ( $\mathrm{pH} \mathrm{5.5)}$ and pre-heated at $37^{\circ} \mathrm{C}$ for 5 minutes. $1.55 \mu \mathrm{l}$ of ${ }^{177} \mathrm{Lu}$ were added to the reaction mixture (222MBq/ $\mathrm{mg}$ ) and incubated at $37^{\circ} \mathrm{C}$ for 45 minutes. The reaction was stopped by adding $100 \mu \mathrm{l}$ of formulation buffer (6.7mM PBS, 7.5\% BSA, 1 mM DTPA, pH 7.5). Radiochemical purity was determined by thin layer chromatography (TLC) analysis using $1 \mu \mathrm{l}$ of the reaction. Separation was done in a migration vial containing $1 \mathrm{ml}$ of $0.9 \% \mathrm{NaCl}$. The radiolabeling yield was generally above $99 \%$. The immunoreactivity of the DOTA-conjugated antibody was compared with that of the naked antibody by flow cytometry analysis. Briefly, about $5 \times 10^{5}$ cells were blocked in PBS/ $1 \%$ BSA for 30 minutes and then incubated at $4{ }^{\circ} \mathrm{C}$ with $10 \mu \mathrm{g} / \mathrm{mL}$ DOTA-conjugatedMAbs (3C23K or R565), non-conjugated 3C23K or R565 MAbs, or PBS/1\% BSA (control cells, auto-fluorescence assay) for 90 minutes. After washing, cells were incubated with FITC-conjugated anti-human $\operatorname{IgG}\left(0.05 \mu \mathrm{g} / 10^{6}\right.$ cellules $)$ at $4^{\circ} \mathrm{C}$ for $1 \mathrm{~h}$. Cells were analyzed using a FC500 flow cytometer (Beckman Coulter).

\section{SPECT-CT imaging of mouse xenografts}

Eight mice were xenografted with COV434-MISRII or COV434-WT cells, as described above. When tumors reached a volume of about $200 \mathrm{~mm}^{3}, 250 \mu \mathrm{l}$ of $11 \mathrm{MBq}$ (46 $\mu \mathrm{g}$ of $3 \mathrm{C} 23 \mathrm{~K}$ at $200 \mathrm{MBq} / \mathrm{mg}$ ) ${ }^{177} \mathrm{Lu}-3 \mathrm{C} 23 \mathrm{~K}$ (direct binding study) were i.p. injected in two COV434-WT- and two COV434-MISRII-xenografted mice. Four other mice were used for the isotopic dilution study that consisted in an i.p. injection of naked $3 \mathrm{C} 23 \mathrm{~K}$ at therapeutic dose $(20 \mathrm{mg} / \mathrm{kg})$ prior to injection of ${ }^{177} \mathrm{Lu}-3 \mathrm{C} 23 \mathrm{~K}$.

At different time points $(24,48,72$ and 144 hours post-injection), whole-body SPECT/CT images were acquired using a four-headed NanoSPECT imager (Bioscan Inc., Washington DC). The system was equipped with a tungsten-based collimator with nine $1 \mathrm{~mm}$-diameter pinholes. The energy window was centered at $210 \mathrm{keV}$ with $\pm 20 \%$ width. Acquisition times were defined to obtain 30,000 counts for each projection (generally $60-120$ seconds were required) with 24 projections. The total scan time was generally around 30-60 minutes. Concurrent micro-CT whole-body images were acquired (55kV, 500 milliseconds, 240 projections) for anatomic co-registration with the SPECT data. Reconstructed data from SPECT and CT images were visualized and coregistered using Invivoscope ${ }^{\circledR}$. Images and maximum intensity projections (MIPs) were reconstructed using the dedicated Invivoscope ${ }^{\circledR}$ (Bioscan, Inc., Washington, USA) and Mediso InterViewXP ${ }^{\circledR}$ software programs (Mediso, Budapest, Hungary). The InvivoQuant ${ }^{\mathbb{B}}$ software was alternatively used for image reconstruction.

\section{ACKNOWLEDGMENTS AND FUNDING}

We thank Véronique Garambois and Sabine Bousquié for excellent technical assistance. This work was supported by the grant Projet collaboratif de R\&D FEDER/Oséo "MISR-test" from Région LanguedocRoussillon/Occitanie. This work was supported by the 
program "Investissement d'Avenir" (grant agreement: Labex MabImprove, ANR-10-LABX-53-01).

\section{CONFLICTS OF INTEREST}

Isabelle Navarro-Teulon and André Pèlegrin are inventors of the WO 2008/053330 patent "Monolonal antibodies and fragment thereof directed against the human anti-mülllerian hormone type II receptor (AMHR-II)". Isabelle Teulon is also inventor of the WO2011141653A1 patent "Novel mutated humanized 12g4 antibodies and the fragments thereof against the human anti-müllerian hormone receptor type II". Isabelle Teulon and Christine Gaucher are inventors of the WO 2013093379A1 "Novel pharmaceutical compositions comprising an antibody which binds the human anti-mullerian hormone receptor type II". Jean-François Prost and Jean-Marc Barret are employed by GamaMabs Pharma.

\section{REFERENCES}

1. Itamochi H. Targeted therapies in epithelial ovarian cancer: Molecular mechanisms of action. World J Biol Chem. 2010; 1:209-20.

2. Torre LA, Bray F, Siegel RL, Ferlay J, Lortet-Tieulent J, Jemal A. Global cancer statistics, 2012. CA Cancer J Clin. 2015; 65:87-108

3. Siegel RL, Miller KD, Jemal A. Cancer statistics, 2016. CA Cancer J Clin. 2016; 66:7-30.

4. Leffers N, Daemen T, Helfrich W, Boezen HM, Cohlen BJ, Melief CJM, Nijman HW. Antigen-specific active immunotherapy for ovarian cancer. Cochrane Database Syst Rev. 2014; 9:CD007287.

5. Lokadasan R, James FV, Narayanan G, Prabhakaran PK. Targeted agents in epithelial ovarian cancer: review on emerging therapies and future developments. Ecancermedicalscience. 2016; 10:626.

6. Clarke T, Galaal K, Bryant A, Naik R. Evaluation of followup strategies for patients with epithelial ovarian cancer following completion of primary treatment. Cochrane Database Syst Rev. 2014; 9:CD006119.

7. Bellati F, Napoletano C, Gasparri ML, Visconti V, Zizzari IG, Ruscito I, Caccetta J, Rughetti A, Benedetti-Panici P, Nuti M. Monoclonal antibodies in gynecological cancer: a critical point of view. Clin Dev Immunol. 2011; 2011:890758.

8. Reichert JM, Dhimolea E. The future of antibodies as cancer drugs. Drug Discov Today. 2012; 17:954-63.

9. Sato S, Itamochi H. Profile of farletuzumab and its potential in the treatment of solid tumors. OncoTargets Ther. 2016; 9:1181-8

10. Al Wadi K, Ghatage P. Efficacy of trebananib (AMG $386)$ in treating epithelial ovarian cancer. Expert Opin Pharmacother. 2016; 17:853-60.

11. Romero I, Bast RC. Minireview: human ovarian cancer: biology, current management, and paths to personalizing therapy. Endocrinology. 2012; 153:1593-602.
12. Josso N, Racine C, di Clemente N, Rey R, Xavier F. The role of anti-Müllerian hormone in gonadal development. Mol Cell Endocrinol. 1998; 145:3-7.

13. Kim JH, MacLaughlin DT, Donahoe PK. Müllerian inhibiting substance/anti-Müllerian hormone: A novel treatment for gynecologic tumors. Obstet Gynecol Sci. 2014; 57:343-57.

14. Wang PY, Koishi K, McGeachie AB, Kimber M, Maclaughlin DT, Donahoe PK, McLennan IS. Mullerian inhibiting substance acts as a motor neuron survival factor in vitro. Proc Natl Acad Sci U S A. 2005; 102:16421-5.

15. Cimino I, Casoni F, Liu X, Messina A, Parkash J, Jamin SP, Catteau-Jonard S, Collier F, Baroncini M, Dewailly D, Pigny P, Prescott M, Campbell R, et al. Novel role for anti-Müllerian hormone in the regulation of GnRH neuron excitability and hormone secretion. Nat Commun. 2016; 7:10055.

16. Masiakos PT, MacLaughlin DT, Maheswaran S, Teixeira J, Fuller AF, Shah PC, Kehas DJ, Kenneally MK, Dombkowski DM, Ha TU, Preffer FI, Donahoe PK. Human ovarian cancer, cell lines, and primary ascites cells express the human Mullerian inhibiting substance (MIS) type II receptor, bind, and are responsive to MIS. Clin Cancer Res Off J Am Assoc Cancer Res. 1999; 5:3488-99.

17. Bakkum-Gamez JN, Aletti G, Lewis KA, Keeney GL, Thomas BM, Navarro-Teulon I, Cliby WA. Müllerian inhibiting substance type II receptor (MISIIR): a novel, tissue-specific target expressed by gynecologic cancers. Gynecol Oncol. 2008; 108:141-8.

18. Song JY, Chen KY, Kim SY, Kim MR, Ryu KS, Cha JH, Kang CS, MacLaughlin DT, Kim JH. The expression of Müllerian inhibiting substance/anti-Müllerian hormone type II receptor protein and mRNA in benign, borderline and malignant ovarian neoplasia. Int J Oncol. 2009; 34:1583-91.

19. Anttonen M, Färkkilä A, Tauriala H, Kauppinen M, Maclaughlin DT, Unkila-Kallio L, Bützow R, Heikinheimo M. Anti-Müllerian hormone inhibits growth of AMH type II receptor-positive human ovarian granulosa cell tumor cells by activating apoptosis. Lab Investig J Tech Methods Pathol. 2011; 91:1605-14.

20. Kersual N, Garambois V, Chardès T, Pouget JP, Salhi I, Bascoul-Mollevi C, Bibeau F, Busson M, Vié H, Clémenceau B, Behrens CK, Estupina P, Pèlegrin A, et al. The human Müllerian inhibiting substance type II receptor as immunotherapy target for ovarian cancer. Validation using the mAb 12G4. mAbs. 2014; 6:1314-26.

21. Pépin D, Sosulski A, Zhang L, Wang D, Vathipadiekal V, Hendren K, Coletti CM, Yu A, Castro CM, Birrer MJ, Gao G, Donahoe PK. AAV9 delivering a modified human Mullerian inhibiting substance as a gene therapy in patient-derived xenografts of ovarian cancer. Proc Natl Acad Sci U S A. 2015; 112:E4418-4427.

22. Connolly DC, Bao R, Nikitin AY, Stephens KC, Poole TW, Hua X, Harris SS, Vanderhyden BC, Hamilton TC. Female mice chimeric for expression of the simian virus $40 \mathrm{TAg}$ 
under control of the MISIIR promoter develop epithelial ovarian cancer. Cancer Res. 2003; 63:1389-97.

23. Pieretti-Vanmarcke R, Donahoe PK, Szotek P, Manganaro T, Lorenzen MK, Lorenzen J, Connolly DC, Halpern EF, MacLaughlin DT. Recombinant human Mullerian inhibiting substance inhibits long-term growth of MIS type II receptordirected transgenic mouse ovarian cancers in vivo. Clin Cancer Res Off J Am Assoc Cancer Res. 2006; 12:1593-8.

24. Stephen AE, Masiakos PT, Segev DL, Vacanti JP, Donahoe PK, MacLaughlin DT. Tissue-engineered cells producing complex recombinant proteins inhibit ovarian cancer in vivo. Proc Natl Acad Sci U S A. 2001; 98:3214-9.

25. Salhi I, Cambon-Roques S, Lamarre I, Laune D, Molina F, Pugnière $M$, Pourquier D, Gutowski M, Picard JY, Xavier F, Pèlegrin A, Navarro-Teulon I. The anti-Müllerian hormone type II receptor: insights into the binding domains recognized by a monoclonal antibody and the natural ligand. Biochem J. 2004; 379:785-93.

26. Schroff RW, Foon KA, Beatty SM, Oldham RK, Morgan AC. Human anti-murine immunoglobulin responses in patients receiving monoclonal antibody therapy. Cancer Res. 1985; 45:879-85.

27. Mondon P, Souyris N, Douchy L, Crozet F, Bouayadi K, Kharrat $\mathrm{H}$. Method for generation of human hyperdiversified antibody fragment library. Biotechnol J. 2007; 2:76-82.

28. Beliard R, Waegemans T, Notelet D, Massad L, Dhainaut F, Romeuf C de, Guemas E, Haazen W, Bourel D, Teillaud JL, Prost JF. A human anti-D monoclonal antibody selected for enhanced FcgammaRIII engagement clears RhD+ autologous red cells in human volunteers as efficiently as polyclonal anti-D antibodies. Br J Haematol. 2008; 141:109-19.

29. de Romeuf C, Dutertre CA, Le Garff-Tavernier M, Fournier N, Gaucher C, Glacet A, Jorieux S, Bihoreau N, Behrens CK, Béliard R, Vieillard V, Cazin B, Bourel D, et al. Chronic lymphocytic leukaemia cells are efficiently killed by an anti-CD20 monoclonal antibody selected for improved engagement of FcgammaRIIIA/CD16. Br J Haematol. 2008; 140:635-43.

30. Sibéril S, de Romeuf C, Bihoreau N, Fernandez N, Meterreau JL, Regenman A, Nony E, Gaucher C, Glacet A, Jorieux S, Klein P, Hogarth MP, Fridman $\mathrm{WH}$, et al. Selection of a human anti-RhD monoclonal antibody for therapeutic use: impact of IgG glycosylation on activating and inhibitory Fc gamma R functions. Clin Immunol Orlando Fla. 2006; 118:170-9.

31. Ehrenmann F, Kaas Q, Lefranc MP. IMGT/3DstructureDB and IMGT/DomainGapAlign: a database and a tool for immunoglobulins or antibodies, T cell receptors, MHC, IgSF and MhcSF. Nucleic Acids Res. 2010; 38:D301-307.

32. Giudicelli V, Duroux P, Ginestoux C, Folch G, JabadoMichaloud J, Chaume D, Lefranc MP. IMGT/LIGM-DB, the IMGT comprehensive database of immunoglobulin and
T cell receptor nucleotide sequences. Nucleic Acids Res. 2006; 34:D781-784.

33. Mondon P, Grand D, Souyris N, Emond S, Bouayadi K, Kharrat H. Mutagen: a random mutagenesis method providing a complementary diversity generated by human error-prone DNA polymerases. Methods Mol Biol Clifton NJ. 2010; 634:373-86.

34. Bruhns P. Properties of mouse and human IgG receptors and their contribution to disease models. Blood. 2012; 119:5640-9.

35. Overdijk MB, Verploegen S, Ortiz Buijsse A, Vink T, Leusen JHW, Bleeker WK, Parren PWHI. Crosstalk between human IgG isotypes and murine effector cells. J Immunol Baltim Md 1950. 2012; 189:3430-8.

36. Junttila TT, Parsons K, Olsson C, Lu Y, Xin Y, Theriault J, Crocker L, Pabonan O, Baginski T, Meng G, Totpal K, Kelley RF, Sliwkowski MX. Superior in vivo efficacy of afucosylated trastuzumab in the treatment of HER2-amplified breast cancer. Cancer Res. 2010; 70:4481-9.

37. Könitzer JD, Sieron A, Wacker A, Enenkel B. Reformatting Rituximab into Human IgG2 and IgG4 Isotypes Dramatically Improves Apoptosis Induction In Vitro. PloS One. 2015; 10:e0145633.

38. Kesselring R, Thiel A, Pries R, Fichtner-Feigl S, Brunner S, Seidel P, Bruchhage KL, Wollenberg B. The complement receptors CD46, CD55 and CD59 are regulated by the tumour microenvironment of head and neck cancer to facilitate escape of complement attack. Eur J Cancer Oxf Engl 1990. 2014; 50:2152-61.

39. Kristedja TS, Morgan RJ, Cristea M. Targeted agents in ovarian cancer. Womens Health Lond Engl. 2010; 6:679-94.

40. Song J, Cao W, Li F, Shi L, Jia X. Anti-Sp17 monoclonal antibody with antibody-dependent cell-mediated cytotoxicity and complement-dependent cytotoxicity activities against human ovarian cancer cells. Med Oncol Northwood Lond Engl. 2012; 29:2923-31.

41. Yver A, Homery MC, Fuseau E, Guemas E, Dhainaut F, Quagliaroli D, Beliard R, Prost JF. Pharmacokinetics and safety of roledumab, a novel human recombinant monoclonal anti-RhD antibody with an optimized $\mathrm{Fc}$ for improved engagement of FC $\gamma$ RIII, in healthy volunteers. Vox Sang. 2012; 103:213-22.

42. Church AK, VanDerMeid KR, Baig NA, Baran AM, Witzig TE, Nowakowski GS, Zent CS. Anti-CD20 monoclonal antibody-dependent phagocytosis of chronic lymphocytic leukaemia cells by autologous macrophages. Clin Exp Immunol. 2016; 183:90-101.

43. Golay J, Da Roit F, Bologna L, Ferrara C, Leusen JH, Rambaldi A, Klein C, Introna M. Glycoengineered CD20 antibody obinutuzumab activates neutrophils and mediates phagocytosis through CD16B more efficiently than rituximab. Blood. 2013; 122:3482-91. 
44. Delord JP, Tabernero J, García-Carbonero R, Cervantes A, Gomez-Roca C, Bergé Y, Capdevila J, Paz-Ares L, Roda D, Delmar P, Oppenheim D, Brossard SS, Farzaneh F, et al. Open-label, multicentre expansion cohort to evaluate imgatuzumab in pre-treated patients with KRAS-mutant advanced colorectal carcinoma. Eur J Cancer Oxf Engl 1990. 2014; 50:496-505.

45. Mirschberger C, Schiller CB, Schräml M, Dimoudis N, Friess T, Gerdes CA, Reiff U, Lifke V, Hoelzlwimmer G, Kolm I, Hopfner KP, Niederfellner G, Bossenmaier B. RG7116, a therapeutic antibody that binds the inactive HER3 receptor and is optimized for immune effector activation. Cancer Res. 2013; 73:5183-94.

46. Hirschhorn $\mathrm{T}$, di Clemente N, Amsalem AR, Pepinsky RB, Picard JY, Smorodinsky NI, Cate RL, Ehrlich $\mathrm{M}$. Constitutive negative regulation in the processing of the anti-Müllerian hormone receptor II (AMHRII). J Cell Sci. 2015; 128:1352-64.

47. Liu SD, Chalouni C, Young JC, Junttila TT, Sliwkowski MX, Lowe JB. Afucosylated antibodies increase activation of Fc $\gamma$ RIIIa-dependent signaling components to intensify processes promoting ADCC. Cancer Immunol Res. 2015; 3:173-83.

48. Liu SD, Lowe JB. Implications of understanding the signaling, cellular, and cytotoxic mechanisms afforded by afucosylated antibodies. Oncoimmunology. 2015; 4:e1009288.

49. Clynes RA, Towers TL, Presta LG, Ravetch JV. Inhibitory Fc receptors modulate in vivo cytoxicity against tumor targets. Nat Med. 2000; 6:443-6.

50. Musolino A, Naldi N, Bortesi B, Pezzuolo D, Capelletti M, Missale G, Laccabue D, Zerbini A, Camisa R, Bisagni G, Neri TM, Ardizzoni A. Immunoglobulin G fragment C receptor polymorphisms and clinical efficacy of trastuzumab-based therapy in patients with HER-2/neupositive metastatic breast cancer. J Clin Oncol Off J Am Soc Clin Oncol. 2008; 26:1789-96.

51. Bibeau F, Lopez-Crapez E, Di Fiore F, Thezenas S, Ychou M, Blanchard F, Lamy A, Penault-Llorca F, Frébourg T, Michel $\mathrm{P}$, Sabourin JC, BoissièreMichot F. Impact of Fc \{gamma $\}$ RIIa-Fc $\{$ gamma $\}$ RIIIa polymorphisms and KRAS mutations on the clinical outcome of patients with metastatic colorectal cancer treated with cetuximab plus irinotecan. J Clin Oncol Off J Am Soc Clin Oncol. 2009; 27:1122-9.
52. Shi Y, Fan X, Deng H, Brezski RJ, Rycyzyn M, Jordan RE, Strohl WR, Zou Q, Zhang N, An Z. Trastuzumab triggers phagocytic killing of high HER2 cancer cells in vitro and in vivo by interaction with $\mathrm{Fc} \gamma$ receptors on macrophages. $\mathrm{J}$ Immunol Baltim Md 1950. 2015; 194:4379-86.

53. Barret JM, Pèlegrin A, Decaudin D, de Romeuf C, Duclos ME, Bousseau A, Combot-Plétan C, Prost JF. Preclinical profile of GM102, a first-in-class antibody targeting AMHRII in ovarian cancers. ASCO Meet Abstr. 2016; 34:e23196.

54. Pelat T, Bedouelle H, Rees AR, Crennell SJ, Lefranc MP, Thullier P. Germline humanization of a non-human primate antibody that neutralizes the anthrax toxin, by in vitro and in silico engineering. J Mol Biol. 2008; 384:1400-7.

55. Szabo Z, Guttman A, Bones J, Karger BL. Rapid high-resolution characterization of functionally important monoclonal antibody $\mathrm{N}$-glycans by capillary electrophoresis. Anal Chem. 2011; 83:5329-36.

56. Sali A, Potterton L, Yuan F, van Vlijmen H, Karplus M. Evaluation of comparative protein modeling by MODELLER. Proteins. 1995; 23:318-26.

57. Rocchia W, Sridharan S, Nicholls A, Alexov E, Chiabrera A, Honig B. Rapid grid-based construction of the molecular surface and the use of induced surface charge to calculate reaction field energies: applications to the molecular systems and geometric objects. J Comput Chem. 2002; 23:128-37.

58. Zhang H, Vollmer M, De Geyter M, Litzistorf Y, Ladewig A, Dürrenberger M, Guggenheim R, Miny P, Holzgreve W, De Geyter C. Characterization of an immortalized human granulosa cell line (COV434). Mol Hum Reprod. 2000; 6:146-53.

59. Repetto-Llamazares AHV, Larsen RH, Patzke S, Fleten KG, Didierlaurent D, Pichard A, Pouget JP, Dahle J. Targeted Cancer Therapy with a Novel Anti-CD37 Beta-Particle Emitting Radioimmunoconjugate for Treatment of NonHodgkin Lymphoma. PloS One. 2015; 10:e0128816.

60. Hayes JM, Frostell A, Cosgrave EFJ, Struwe WB, Potter O, Davey GP, Karlsson R, Anneren C, Rudd PM. Fc gamma receptor glycosylation modulates the binding of $\mathrm{IgG}$ glycoforms: a requirement for stable antibody interactions. J Proteome Res. 2014; 13:5471-85. 